\title{
Prevention Strategies to Minimize the Infection Risk Associated with Biologic and Targeted Immunomodulators
}

This article was published in the following Dove Press journal:

Infection and Drug Resistance

\author{
Elaheh Kordzadeh-Kermani ${ }^{1}$ \\ Hossein Khalili' \\ Iman Karimzadeh (iD ${ }^{2}$ \\ Mohammadreza Salehi ${ }^{3}$ \\ 'Department of Clinical Pharmacy, \\ School of Pharmacy, Tehran University of \\ Medical Sciences, Tehran, Iran; \\ ${ }^{2}$ Department of Clinical Pharmacy, \\ School of Pharmacy, Shiraz University of \\ Medical Sciences, Shiraz, Iran; \\ ${ }^{3}$ Department of Infectious Diseases, \\ School of Medicine, Tehran University of \\ Medical Sciences, Tehran, Iran
}

\begin{abstract}
The introduction of biologic and targeted immunomodulators is a significant breakthrough in the therapeutic area of various fields of medicine. The occurrence of serious infections, a complication of secondary immunosuppression associated with these agents, leads to increased morbidity and mortality. Implementing preventive strategies could minimize infection-related complications and improve therapeutic outcomes. The purpose of this review is to focus on current evident approaches regarding screening, monitoring, preventing (immunization and chemoprophylaxis), and management of infections in patients who are candidates for about 70 biologic and targeted immunomodulators. Recommendations are based on relevant guidelines, especially the ESCMID Study Group for Infections in Compromised Hosts (ESGICH) Consensus Document series published in 2018.
\end{abstract}

Keywords: biologic immunomodulators, targeted immunomodulators, immunization, chemoprophylaxis

\section{Introduction}

Biologic immunomodulators are biosimilar medications synthesized by living organisms structurally related to antibodies, interleukins, and receptors that specifically target oncogenic cells or immune system pathways. ${ }^{1}$ Targeted immunomodulators such as BCR-ABL tyrosine kinase inhibitors, phosphatidylinositol-3-kinase inhibitor, bruton tyrosine kinase inhibitors, and mammalian target of rapamycin (mTOR) inhibitors are small molecules which affect intracellular signaling cascades that eventually modulate protein expression. ${ }^{2}$

The availability of biologic and targeted immunomodulators has revolutionized pharmacotherapy of diseases in diverse aspects of medicine, including onco-hematology, rheumatology, nephrology, transplantation, neurology, pulmonology, and dermatology. Despite their therapeutic benefit, concerns regarding the potential risk of infections have been a challenge for using these agents in clinical practice. ${ }^{3}$ Severe infection is a significant cause of morbidity and mortality in patients treated with immunosuppressants. Most patients on immunomodulator drugs require long term therapies; however, a significant number of these patients do not receive appropriate preventive care regarding infections. ${ }^{4}$

Biologic and targeted immunomodulators are categorized into several pharmacologic classes. Unlike traditional immunosuppressants, immune suppression associated with these agents is specific to certain signals in the immune system, occasionally
Correspondence: Hossein Khalil

Department of Clinical Pharmacy, School of Pharmacy, Tehran University of Medical

Sciences, P.o. Box I4I55/645I, Tehran, Iran

Tel/Fax +982166954709

Email khalilih@tums.ac.ir 
causing profound immune suppression mimicking primary immunodeficiency disorders. ${ }^{5-7}$ Depending on their mechanism of action and impact on the immune system, the infection risk associated with these therapies varies among pharmacologic classes; some affect intracellular signaling pathways, some bind to receptors of cellular immunity while some others inhibit the actions of cytokines (Table 1).

The European Society of Clinical Microbiology and Infectious Diseases (ESCMID) Study Group for Infections in Compromised Hosts Consensus have reviewed articles and made recommendations to instruct clinicians on the strategies to prevent and manage infections associated with biologic and targeted immunomodulators. ${ }^{8-13}$ In this review, we aim to focus on evidence-based strategies according to the latest guidelines to provide practitioners guidance regarding screening, chemoprophylaxis, vaccination, and management of infections in patients on biologic and targeted immunomodulators.

\section{Methods}

We conducted a literature search in databases including Scopus, Medline, Embase, Cochrane Database Systematic Reviews and Google Scholar from January 2007 to August 2019 using the search terms related to each of the agents along with "infection", "vaccination", "screening", "prophylaxis", "monitoring", "immunization", "immune response", "treatment", and "management". Polyclonal antibodies (e.g., anti-thymocyte globulin, rozrolimupab), and monoclonal antibodies that lack prominent immunosuppressive effects (e.g., trastuzumab) were beyond the scope of our review and are not considered here. We included articles and guidelines from the latest updates of ESCMID, The Infectious Diseases Society of America (IDSA), The European League Against Rheumatism (EULAR), National Comprehensive Cancer Network (NCCN), American College of Rheumatology (ACR), American College of Gastroenterology (ACG), The American Association for the Study of Liver Diseases (AASLD), The Canadian Dermatology Association (CDA), European Conference on Infections in Leukaemia (ECIL), The Advisory Committee on Immunization Practices (ACIP), The American Society of Transplantation (AST), European Conference on Infections in Leukaemia (ECIL), The German Society of Hematology and Medical Oncology and the International Consensus Guidelines on the Management of Cytomegalovirus. ${ }^{8-29}$ We also included recommendations from Uptodate online, the relevant review articles, expert opinions, and European Medicines Agency (EMA) drug labels, especially on subjects that the guidelines do not offer an opinion. The recommendations regarding screening for infections, immunization, prevention, and monitoring of infections in patients candidates for biologic and targeted immunomodulators were finally categorized by the class of immunosuppressive agents.

\section{Results}

Of the relevant articles we found, data were obtained from 31 guidelines as well as consensus recommendations and 17 review papers. Comprehensive recommendations were not found on subjects such as prophylactic measures for prevention of pneumocystis pneumonia in biologic therapy of rheumatologic diseases, screening of infections for patients undergoing basiliximab induction, preventive measures to prevent infections associated with abatacept, immunization in patients undergoing treatment with new generations of anti-CD20 monoclonal antibodies and late onset neutropenia associated with anti-CD20 monoclonal antibodies. Such data were obtained from expert opinions, review articles, the EMA drug labels and clinical trials. The recommendations regarding screening, prophylaxis, monitoring, and immunization of infections associated with biologic and targeted immunomodulators are summarized in Tables 2-5.

\section{Discussion}

The growing number of approved biologic and targeted immunomodulators on the market and their various approved and off-label indications explain the necessity to guide health care professionals in the prevention and management of infections and define the relative risk of particular infections associated with these agents. This study reviewed and summarized prevention strategies, including screening, monitoring, immunization, prophylaxis, and management of infections associated with about 70 biologic and targeted therapies based on relevant guidelines, especially ESCMID Study Group for Infections in Compromised Hosts (ESGICH) Consensus document series published in 2018..$^{8-13}$

\section{The Risk of Hepatitis B Virus (HBV) Reactivation}

Extensive studies have shown that the risk of $\mathrm{HBV}$ reactivation is highest with anti-CD20 targeted agents including rituximab, ofatumumab, obinutuzumab, ${ }^{27,30}$ and probably ocrelizumab. ${ }^{31}$ These agents are associated with a significant risk of HBV reactivation in both $\mathrm{HBs} \mathrm{Ag}$-positive and $\mathrm{HBs}$ Ag-negative/ anti-HBc-positive patients. Studies have shown that tenofovir and entecavir are significantly more effective than lamivudine 
Table I Biologic and Targeted Immunomodulators Classification and Their Impacts on the Immune System

\begin{tabular}{|c|c|c|}
\hline Biologic and Targeted Immunomodulators & Effect on the Immune System & Risk of Infections \\
\hline $\begin{array}{l}\text { TNF inhibitors } \\
\text { Infliximab, Adalimumab, Golimumab, Certolizumab, } \\
\text { Etanercept }\end{array}$ & Inactivation of CD4+/CD 8+ $\mathrm{T}$ cells; neutropenia & TB, HBV \\
\hline $\begin{array}{l}\text { Co-stimulation modulator } \\
\text { Abatacept }\end{array}$ & $\begin{array}{l}\text { Inhibition of APC function; inhibition of } T \text { cell } \\
\text { stimulation; inhibition of B cell response }\end{array}$ & $\begin{array}{l}\text { Not associated with increased } \\
\text { risk of infection }\end{array}$ \\
\hline $\begin{array}{l}\text { IL-I targeted agents } \\
\text { Anakinra, Canakinumab, Rilonacept }\end{array}$ & $\downarrow$ IL-I & TB \\
\hline $\begin{array}{l}\text { CDI9 targeted agents } \\
\text { Blinatumomab, Inebilizumab }\end{array}$ & $\begin{array}{l}\downarrow \text { CDI9 B Cells; } \downarrow \text { plasmablasts; } \\
\text { hypogammaglobulinemia }\end{array}$ & Limited data \\
\hline $\begin{array}{l}\text { CD22 targeted agents } \\
\text { Epratuzumab, Inotuzumab Ozogamicin, Moxetumomab } \\
\text { Pasudotox }\end{array}$ & Inhibition of B cell proliferation & $\begin{array}{l}\text { Not associated with increased } \\
\text { risk of infection }\end{array}$ \\
\hline $\begin{array}{l}\text { CD30 targeted agents } \\
\text { Brentuximab Vedotin }\end{array}$ & Antibody-dependent cellular cytotoxicity; neutropenia & $\mathrm{HZ}, \mathrm{PCP}, \mathrm{CMV}, \mathrm{PML}$ \\
\hline $\begin{array}{l}\text { CD38 targeted agents } \\
\text { Daratumumab, Isatuximab }\end{array}$ & Complement-dependent cytotoxicity & VZV (probably) \\
\hline $\begin{array}{l}\text { CD40 targeted agents } \\
\text { Dacetuzumab, Lucatumumab }\end{array}$ & $\downarrow B$ Cells; impairment in $T$ cell function & $\begin{array}{l}\text { CMV, PCP Cryptococcus, } \\
\text { Cryptosporidium }\end{array}$ \\
\hline $\begin{array}{l}\text { CD319-targeted agent } \\
\text { Elotuzumab }\end{array}$ & Lymphopenia & VZV \\
\hline $\begin{array}{l}\text { CCR4 targeted agent } \\
\text { Mogamulizumab }\end{array}$ & Lymphopenia & $\mathrm{HBV}, \mathrm{HZ}, \mathrm{CMV}$ \\
\hline $\begin{array}{l}\text { Anti-CD20 monoclonal antibodies } \\
\text { Rituximab, Ibritumomab Tiuxetan, Ofatumumab, } \\
\text { Ocrelizumab }\end{array}$ & $\downarrow$ CD20 B Cells; neutropenia; hypogammaglobulinemia & $\begin{array}{l}\text { HBV, HCV, VZV, PML, PCP, } \\
\text { Enterovirus }\end{array}$ \\
\hline $\begin{array}{l}\text { Anti-CD52 monoclonal antibody } \\
\text { Alemtuzumab }\end{array}$ & $\begin{array}{l}\text { Inhibition of the action of CD4+ T Cells, B Cells } \\
\text { epithelial cells, macrophages, and monocytes }\end{array}$ & HSV, PCP, TB, VZV, HPV \\
\hline $\begin{array}{l}\text { Component } 5 \text { (C5) targeted agent } \\
\text { Eculizumab }\end{array}$ & Complement-mediated cytotoxicity & $\begin{array}{l}\text { Neisseria, H. influenzae, } \\
\text { S. pneumonia, } \\
\text { Aspergillosis }\end{array}$ \\
\hline $\begin{array}{l}\text { BAFF inhibitor } \\
\text { Belimumab }\end{array}$ & Reduction of B cell population & PML (Rare) \\
\hline $\begin{array}{l}\alpha 4 \text {-integrin targeted agent } \\
\text { Natalizumab }\end{array}$ & $\begin{array}{l}\text { Targeting } \alpha 4 \text {-integrin; } \\
\text { inhibition of translocation of leukocytes in BBB }\end{array}$ & PML \\
\hline $\begin{array}{l}\alpha 4 \text {-integrin targeted agent } \\
\text { Vedolizumab }\end{array}$ & $\begin{array}{l}\text { Targeting } \alpha 4 \beta 7 \text { integrin; } \\
\text { inhibition of translocation of leukocytes in the mucosal } \\
\text { membrane of the small intestine }\end{array}$ & $\begin{array}{l}\text { Enteric bacterial infections } \\
\text { (probably) }\end{array}$ \\
\hline $\begin{array}{l}\text { IgE targeted agent } \\
\text { Omalizumab }\end{array}$ & $\begin{array}{l}\text { Inhibition of the activity of mast cells, basophils, plasma } \\
\text { cells, and eosinophils }\end{array}$ & Helminth infections \\
\hline $\begin{array}{l}\text { IL-5 targeted agent } \\
\text { Mepolizumab, Reslizumab }\end{array}$ & $\downarrow$ IL-5; inhibition of eosinophil differentiation & $\begin{array}{l}\text { Not associated with increased } \\
\text { risk of infection }\end{array}$ \\
\hline
\end{tabular}


Table I (Continued).

\begin{tabular}{|c|c|c|}
\hline Biologic and Targeted Immunomodulators & Effect on the Immune System & Risk of Infections \\
\hline $\begin{array}{l}\text { IL-12 and IL-23 targeted agent } \\
\text { Ustekinumab }\end{array}$ & $\begin{array}{l}\text { Inhibition of action of NK Cells, Th I7, ThI CD4+ } \\
\text { T-cells, } \downarrow \text { IFN } \gamma\end{array}$ & $\begin{array}{l}\text { TB, HBV (intracellular } \\
\text { pathogens) }\end{array}$ \\
\hline $\begin{array}{l}\text { IL-I } 7 \text { targeted agents } \\
\text { Secukinumab, Ixekizumab, Brodalumab }\end{array}$ & $\begin{array}{l}\text { Inhibition of macrophage stimulation and neutrophil } \\
\text { chemotaxis }\end{array}$ & Mucocutaneous candidiasis \\
\hline $\begin{array}{l}\text { Proteasome inhibitors } \\
\text { Bortezomib, Carfilzomib, Ixazomib }\end{array}$ & $\begin{array}{l}\text { Inhibition of the proteasome pathway } \\
\text { Inhibition of the activity of } \mathrm{T} \text { cell }\end{array}$ & $H Z, V Z V$ \\
\hline $\begin{array}{l}\text { BCR-ABL tyrosine kinase inhibitors } \\
\text { Imatinib, Dasatinib, Nilotinib, Ponatinib, Bosutinib }\end{array}$ & $\begin{array}{l}\text { Neutropenia; } \\
\text { Impairment of B cell response; } \\
\text { Reduced CD4+ and CD8+ T cell stimulation }\end{array}$ & HBV, CMV, EBV \\
\hline $\begin{array}{l}\text { mTOR inhibitors } \\
\text { Sirolimus, Everolimus, Temsirolimus }\end{array}$ & $\begin{array}{l}\text { Reduced neutrophil migration; } \\
\text { Inhibition of dendritic cell differentiation; } \\
\text { Inhibition of T cell stimulation }\end{array}$ & Bacterial infections TB, HBV, HZ \\
\hline $\begin{array}{l}\text { JAK inhibitors } \\
\text { Tofacitinib, Ruxolitinib }\end{array}$ & Inhibition of differentiation of $\mathrm{THI}$ and $\mathrm{THI} 7$ cells & $\begin{array}{l}\text { Bacterial infections, PCP, CMV, } \\
\mathrm{HZ} \text {, EBV } \\
\text { Invasive fungal infections }\end{array}$ \\
\hline $\begin{array}{l}\text { Sphingosine I-phosphate receptor modulator } \\
\text { Fingolimod }\end{array}$ & $\begin{array}{l}\text { Lymphopenia } \\
\downarrow \mathrm{CD} 4+\text { and CD8+ T Cells in CSF }\end{array}$ & HZ, PML, Cryptococcus \\
\hline $\begin{array}{l}\text { IL-6 targeted agents } \\
\text { Tocilizumab, Siltuximab }\end{array}$ & Neutropenia & $\begin{array}{l}\text { TB, NTM, HBV, PCP, invasive } \\
\text { candidiasis }\end{array}$ \\
\hline $\begin{array}{l}\text { Agents targeting PD-I/PD-LI } \\
\text { Nivolumab, Pembrolizumab }\end{array}$ & Increase in activity of $T$ cells & $\begin{array}{l}\text { Not associated with increased } \\
\text { risk of the infection itself }\end{array}$ \\
\hline $\begin{array}{l}\text { Agents targeting CTLA-4 } \\
\text { Atezolizumab, Ipilimumab, Tremelimumab }\end{array}$ & Increase in activity of $T$ cells & $\begin{array}{l}\text { Not associated with increased } \\
\text { risk of the infection itself }\end{array}$ \\
\hline $\begin{array}{l}\text { Phosphatidylinositol-3-kinase inhibitor } \\
\text { Idelalisib }\end{array}$ & $\begin{array}{l}\text { Reduced chemotaxis and cytokine production; } \\
\text { neutropenia }\end{array}$ & PCP, CMV \\
\hline $\begin{array}{l}\text { Bruton Tyrosine kinase inhibitors } \\
\text { Ibrutinib, Acalabrutinib }\end{array}$ & $\begin{array}{l}\text { Inhibition of B cell proliferation; } \\
\text { hypogammaglobulinemia }\end{array}$ & Bacterial infections \\
\hline $\begin{array}{l}\text { Monoclonal antibody targeting CD25 } \\
\text { Basiliximab }\end{array}$ & Inhibition of the action of $T$ cells & PCP, CMV \\
\hline
\end{tabular}

Abbreviations: APC, antigen-presenting cell; BAFF, B-cell activating factor, CMV, cytomegalovirus; EBV, Epstein-Barr virus; $H B V$, hepatitis B virus; $H C V$, hepatitis $C$ virus; $H$. influenzae, Haemophilus influenzae, HPV, human papillomavirus; HSV, Herpes simplex virus; HZ, herpes zoster; IFN $\gamma$, interferon-gamma; IL-I, interleukin-I; IL-5, interleukin-5; NTM, Nontuberculous mycobacteria; PCP, Pneumocystis carinii pneumonia; PML, progressive multifocal leukoencephalopathy; TNF, tumor necrosis factor; TB, tuberculosis; VZV, varicella-zoster virus.

in preventing $\mathrm{HBV}$ reactivation in patients on anti-CD20 monoclonal antibodies. ${ }^{32,33}$ Therefore, ESCMID recommends either tenofovir or entecavir-based regimens for antiviral therapy in both active and occult hepatitis B patients who are candidates for anti-CD20 targeted agents. ${ }^{10}$

HBs Ag-positive patients are at high risk of HBV reactivation with alemtuzumab. Also, HBs Ag-negative/anti$\mathrm{HBc}$-positive patients are moderate to high risk for reactivation of hepatitis $\mathrm{B}$; Therefore, ESCMID recommends that all patients with active hepatitis B should receive antiviral prophylaxis. Individuals with occult infection could either receive prophylaxis or be monitored for reactivation of $\mathrm{HBV}$ based on the indication of alemtuzumab and concomitant use of corticosteroids in certain clinical conditions (e.g., transplantation, multiple sclerosis) ${ }^{10,30}$

Anti-TNF monoclonal antibodies are considered as moderate to high risk for reactivation of hepatitis $B$ in active infection and moderate risk for occult infection. The risk of 
Table 2 Evidence and Recommendations on Screening of Infections in Patients Candidates for Biologic and Targeted Immunomodulatory Therapies

\begin{tabular}{|c|c|}
\hline TNF inhibitors & $\begin{array}{l}\text { Perform PPD and IGRA; Chest X-ray; smear and culture of the sputum. }{ }^{13} \\
\text { Check HBs Ag and anti-HBc. Check anti-HBs for immunization status. }{ }^{13} \\
\text { Screening pap smear abnormalities could be considered. }{ }^{42}\end{array}$ \\
\hline IL-I-targeted agents & Perform PPD and IGRA; Chest X-ray; smear and culture of the sputum. ${ }^{8}$ \\
\hline CDI9-targeted agents & Check baseline immunoglobulin levels. ${ }^{10}$ \\
\hline CD22-targeted agents & Check HBs Ag and anti-HBc; Check anti HBS Ab for immunization status; Check HBV viral load if necessary. ${ }^{12}$ \\
\hline CD30-targeted agent & Check HBs Ag and anti-HBc; Check anti HBS Ab for immunization status; Check HBV viral load if necessary. ${ }^{12}$ \\
\hline CD-38-targeted agents & $\begin{array}{l}\text { Check VZV serology. }{ }^{12} \\
\text { Check HBs Ag and anti-HBc. Check anti HBS Ab for immunization status. Check HBV viral load if necessary. }{ }^{12}\end{array}$ \\
\hline CD-3|9-targeted agent & Check VZV serology. ${ }^{12}$ \\
\hline CCR4-targeted Agent & Check HBs Ag and anti-HBc. Check anti HBS Ab for immunization status. Check HBV viral load if necessary. ${ }^{12}$ \\
\hline $\begin{array}{l}\text { Anti-CD20 monoclonal } \\
\text { antibodies }\end{array}$ & $\begin{array}{l}\text { Check HBs Ag and anti-HBc. Check anti HBS Ab for immunization status. Check HBV viral load if necessary. }{ }^{10} \\
\text { Check baseline immunoglobulin levels. }{ }^{22,83}\end{array}$ \\
\hline Anti-CD52 monoclonal antibody & $\begin{array}{l}\text { Perform PPD and IGRA; Chest X-ray, smear, and culture of sputum. }{ }^{10} \\
\text { Check HBs Ag and anti-HBc. Check anti HBS Ab for immunization status. Check HBV viral load if necessary. }{ }^{10} \\
\text { Check HCV Ab. }{ }^{10} \\
\text { Check VZV Serology. }{ }^{10} \\
\text { Yearly screening of HPV is recommended in women. }{ }^{10}\end{array}$ \\
\hline T-Cell Co-stimulation Blocker & Check HBs Ag and anti-HBc. Check anti HBS Ab for immunization status. Check HBV viral load if necessary. ${ }^{30}$ \\
\hline $\begin{array}{l}\text { Monoclonal antibodies targeting } \\
\alpha 4 \text {-integrin and } \mathrm{CD} \text { I la }\end{array}$ & $\begin{array}{l}\text { Brain MRI could be considered." } \\
\text { Checking Anti-JCV IgG is recommended. }{ }^{\prime \prime}\end{array}$ \\
\hline IgE targeted agent & Stool exam; Serologic test for Strongyloides stercoralis is recommended. ${ }^{8}$ \\
\hline IL-I2 and IL-23-targeted agent & $\begin{array}{l}\text { Perform PPD and IGRA; Chest X-ray; smear and culture of sputum. }{ }^{8} \\
\text { Check HBs Ag and anti-HBc. Check anti HBS Ab for immunization status. Check HBV viral load if necessary. }\end{array}$ \\
\hline IL-17-targeted agents & Perform PPD and IGRA; Chest X-ray; smear and culture of the sputum. ${ }^{8}$ \\
\hline $\begin{array}{l}\text { Component } 5(\mathrm{C} 5) \text {-targeted } \\
\text { agents }\end{array}$ & Real-time PCR for detection of Neisseria gonorrhoeae in highly sexually active patients ${ }^{8}$ \\
\hline IL-6-targeted agents & $\begin{array}{l}\text { Perform PPD; IGRA; Chest X-ray; smear and culture of sputum. }{ }^{8} \\
\text { Check HBs Ag and anti-HBc. Check anti HBS Ab for immunization status. }^{8}\end{array}$ \\
\hline Proteasome inhibitors & Check VZV serology." \\
\hline Agents targeting PD-I/PD-LI & $\begin{array}{l}\text { Perform PPD and IGRA; Chest X-ray; smear and culture of sputum." } \\
\text { Check HBs Ag and anti-HBc. Check anti HBS Ab for immunization status." } \\
\text { Check HCV Ab." }\end{array}$ \\
\hline $\begin{array}{l}\text { Monoclonal antibodies against } \\
\text { CTLA-4 }\end{array}$ & $\begin{array}{l}\text { Perform PPD and IGRA; Chest X-ray; smear and culture of sputum. }{ }^{\prime \prime} \\
\text { Check HBs Ag and anti-HBc. Check anti HBS Ab for immunization status. }{ }^{\prime \prime} \\
\text { Check HCV Ab. }{ }^{\prime \prime}\end{array}$ \\
\hline $\begin{array}{l}\text { BCR-ABL } \\
\text { Tyrosine kinase inhibitors }\end{array}$ & Check $\mathrm{HBs} \mathrm{Ag}$ and anti-HBc. Check anti HBS Ab for immunization status. Check HBV viral load if necessary. ${ }^{9}$ \\
\hline mTOR Inhibitors & $\begin{array}{l}\text { Perform PPD and IGRA; Chest X-ray; smear and culture of sputum. }{ }^{9} \\
\text { Check HBs Ag and anti-HBc. Check anti HBS Ab for immunization status. }{ }^{9}\end{array}$ \\
\hline
\end{tabular}


Table 2 (Continued).

\begin{tabular}{|l|l|}
\hline JAK inhibitors & $\begin{array}{l}\text { Perform PPD and IGRA; Chest X-ray; Smear and culture of sputum. } \\
\text { Check HBs Ag and anti-HBc. Check anti HBS Ab for immunization status. }\end{array}$ \\
\hline $\begin{array}{l}\text { Sphingosine I-phosphate } \\
\text { receptor modulator }\end{array}$ & $\begin{array}{l}\text { Check baseline CBC. } \\
\text { Check VZV serology. }\end{array}$ \\
\hline $\begin{array}{l}\text { Monoclonal antibody targeting } \\
\text { CD25 }\end{array}$ & $\begin{array}{l}\text { Perform PPD and IGRA; Chest X-ray or Chest CT scan; smear and culture of sputum. } \\
\text { Serologic test for CMV IgG, EBV antibody panel, HSV and VZV IgG, HBsAg, HBcAb, HBsAb, HCV lgG, HIV I } \\
\text { and } 2 \text { antibodies, RPR or TP-PA test for syphilis is recommended according to transplantation protocols. }\end{array}$ \\
\hline
\end{tabular}

Abbreviations: Ab, antibody; CTLA-4, cytotoxic T-lymphocyte-associated protein 4; CMV, cytomegalovirus; EBV, Epstein-Barr virus; HBV, hepatitis B virus; HCV, hepatitis $\mathrm{C}$ virus; $\mathrm{HBs} \mathrm{Ag}$, hepatitis $\mathrm{B}$ surface antigen; HIV, human immunodeficiency viruses; HPV, human papillomavirus; IGRA, interferon-gamma release assay; IL-I, interleukin-I; IL5, interleukin-5; IL-6, interleukin-6; IL-I2, interleukin- I2; IL-I7, interleukin- I7; IL-23, interleukin-23; JAK, Janus kinase; JCV, John Cunningham virus; MRI, Magnetic resonance imaging; mTOR, mammalian target of rapamycin; PCR, Polymerase chain reaction; PDI, programmed death I; PD-L IProgrammed death-ligand I; PPD, purified protein derivative; PML, progressive multifocal leukoencephalopathy ; RPR, rapid plasma reagin; TNF, tumor necrosis factor; TP-PA, Treponema pallidum particle agglutination; VZV, varicella-zoster virus.

HBV reactivation in HBsAg-positive patients is moderate with etanercept, and HBsAg-negative/anti-HBc-positive patients are probably at low risk for seroconversion with etanercept. Accordingly, ESCMID recommends antiviral prophylaxis with either tenofovir or entecavir only for HBsAg-positive patients under TNF inhibitors. ${ }^{13}$

Tocilizumab, abatacept, ustekinumab, mogamulizumab, and BCR-ABL tyrosine kinase inhibitors are associated with a moderate risk of $\mathrm{HBV}$ reactivation. ${ }^{30}$ Data on the risk of $\mathrm{HBV}$ reactivation with tofacitinib is limited; In a study, reactivation of hepatitis B occurred in 2 of $4 \mathrm{HBs}$ Ag positive patients. ${ }^{34}$ Reactivation of HBV did not occur in any of the HBs Ag-negative/anti-HBc-positive patients. Few case reports have demonstrated fatal HBV reactivation in $\mathrm{HBs}$ Ag-positive patients receiving $5-10 \mathrm{mg}$ /day everolimus for renal cell carcinoma and breast cancer. ${ }^{35,36}$ Therefore, ESCMID recommends antiviral prophylaxis only in HBs Ag-positive patients treated with mTOR inhibitors, janus kinase (JAK) inhibitors, BCR-ABL tyrosine kinase inhibitors, IL-6 targeted immunomodulators, ustekinumab, and mogamulizumab. Pre-emptive antiviral prophylaxis is reasonable in occult $\mathrm{HBV}$ infections during treatment with these agents. ${ }^{8-13}$

\section{The Risk of Pneumocystis Carinii Pneumonia (PCP)}

The greatest risk of PCP infection is attributed to alemtuzumab, and universal prophylaxis is required in solid organ transplant recipients and patients with hematologic diseases who have received this agent. Limited data suggest the risk of PCP with bortezomib in multiple myeloma patients treated with high dose corticosteroids; however, the overall risk is low. ${ }^{37,38}$ The incidence of PCP with TNF inhibitors, tocilizumab, and rituximab is also low; however, several studies have demonstrated that the risk of infection is increased in particular conditions including age $>65$ years, concurrent long-term corticosteroid use (e.g., $\geq 15 \mathrm{mg}$ /day prednisolone for more than four weeks), and co-existence of either pulmonary diseases or underlying granulomatosis with polyangiitis. ${ }^{38,39}$ Comparative studies have shown a greater risk with TNF inhibitors, particularly infliximab than tocilizumab. ${ }^{40}$ Eighteen cases of ibrutinib associated PCP have been published; in most of them, the patients were neutropenic. ${ }^{41}$ Currently, trimethoprim/sulfamethoxazole is the drug of choice for the primary prophylaxis of PCP in different clinical conditions such as hematological malignancies and stem cell transplantation. Second-line choices for PCP prophylaxis in the case of trimethoprim/sulfamethoxazole intolerance include pentamidine inhalation, oral dapsone, and oral atovaquone. ${ }^{26}$ These recommendations regarding PCP prophylaxis can be extrapolated to the setting of biologic and targeted immunomodulators.

\section{The Risk of Progressive Multifocal Leukoencephalopathy (PML)}

The incidence of PML appears to be greatest with monoclonal antibodies targeting $\alpha 4$-integrin. PML associated with efalizumab and natalizumab has been reported 1 in 300 patients and 1 in 1000 patients, respectively. ${ }^{42,43}$ In contrast, to date, no case of PML has been reported with vedolizumab. ${ }^{44}$ Fifteen case reports of PML have been reported in patients treated with fingolimod. Treatment duration, age, and JC virus (JCV) antibody titer could be associated with the occurrence of fingolimod-induced PML. ${ }^{45,46}$ Cases of PML have been reported with antiCD20 monoclonal antibodies (15 cases with rituximab and 
Table 3 Evidence and Recommendations on the Prevention and Management of Infections in Patients Candidates for Biologic and Targeted Immunomodulatory Therapies

\begin{tabular}{|c|c|}
\hline \multirow[t]{3}{*}{ TNF Inhibitors } & $\begin{array}{l}\text { Treatment with TNF inhibitors should be started at least one month after initiation of the anti-TB regimen } \\
\text { (isoniazid, rifampin, or the combination of isoniazid and rifampin). } \\
\text { TNF inhibitors should be discontinued if active tuberculosis occurs. }{ }^{13}\end{array}$ \\
\hline & $\begin{array}{l}\text { Tenofovir or Entecavir is recommended for infected HBs Ag-positive patients at least two weeks before the } \\
\text { initiation of TNF inhibitors. Antiviral agents should be continued for at least six months after the withdrawal of } \\
\text { TNF inhibitors. }{ }^{13,85} \\
\text { Antiviral prophylaxis is not recommended in HBs-Ag negative and anti-HBc-positive patients treated with TNF } \\
\text { inhibitors. }{ }^{13} \\
\text { Tenofovir or Entecavir is recommended in the case of HBV reactivation. } \\
\text { TNF inhibitors are not recommended in the acute phase of hepatitis B, chronic untreated hepatitis B, and HBV } \\
\text { infected patients with Child-Pugh B and } \mathrm{C}^{86}\end{array}$ \\
\hline & $\begin{array}{l}\text { Some experts consider PCP prophylaxis for patients with rheumatologic diseases under TNF inhibitors who have } \\
\text { underlying pulmonary diseases or receiving } \geq 15 \mathrm{mg} / \text { day prednisolone for more than four weeks. }{ }^{39}\end{array}$ \\
\hline \multirow[t]{2}{*}{ IL-I-targeted agents } & $\begin{array}{l}\text { In the case of latent tuberculosis, treatment with isoniazid for nine months, rifampin for four months, or the } \\
\text { combination of isoniazid and rifampin for three months is recommended. }\end{array}$ \\
\hline & $\begin{array}{l}\text { Some experts consider PCP prophylaxis for patients with rheumatologic diseases under IL-I targeted agents who } \\
\text { have underlying pulmonary diseases or receiving } \geq 15 \mathrm{mg} / \text { day prednisolone for more than four weeks. }{ }^{39}\end{array}$ \\
\hline CD22-targeted agents & $\begin{array}{l}\text { Antiviral treatment is recommended in HBS-Ag positive patients who are candidates for CD-22 targeted agents. }{ }^{12} \\
\text { Monitoring of HBV viral load is recommended in HBS-Ag negative and anti-HBc-positive patients. }{ }^{12}\end{array}$ \\
\hline \multirow[t]{4}{*}{ CD30-targeted agent } & $\begin{array}{l}\text { Both } \mathrm{HBs} \mathrm{Ag} \text { positive and } \mathrm{HBs} \mathrm{Ag} \text { negative anti-HBc positive patients should receive antiviral prophylaxis before } \\
\text { the administration of brentuximab vedotin. }{ }^{12}\end{array}$ \\
\hline & HSV prophylaxis is recommended in patients on brentuximab vedotin. ${ }^{12}$ \\
\hline & PCP prophylaxis is recommended in patients on brentuximab vedotin. ${ }^{12}$ \\
\hline & $\begin{array}{l}\text { Secondary CMV prophylaxis is recommended in patients with a history of CMV disease who are candidates for } \\
\text { brentuximab vedotin rechallenge. }{ }^{12}\end{array}$ \\
\hline \multirow[t]{3}{*}{ CD38-targeted agents } & $\begin{array}{l}\text { Antiviral treatment could be considered in HBS-Ag positive patients who are candidates for CD-38 targeted agents. }{ }^{12} \\
\text { Monitoring of HBV viral load is recommended in HBS-Ag negative and HBV-Ab positive patients. }{ }^{12}\end{array}$ \\
\hline & $\begin{array}{l}\text { HSV prophylaxis is recommended in VZV seropositive patients at least one week before the administration of } \\
\text { daratumumab and continued for } 12 \text { weeks after discontinuation }{ }^{12}\end{array}$ \\
\hline & PCP prophylaxis is recommended in patients receiving concomitant glucocorticoids, and CD-38 targeted agents. ${ }^{12}$ \\
\hline \multirow[t]{2}{*}{ CD40-targeted agents } & PCP prophylaxis should be considered in patients on CD-40 targeted agents. ${ }^{12}$ \\
\hline & $\begin{array}{l}\text { Regular monitoring of CMV PCR and signs, as well as symptoms of CMV disease, are recommended in patients on } \\
\text { CD-40 targeted agents. }{ }^{12}\end{array}$ \\
\hline \multirow[t]{2}{*}{ CD319-targeted agents } & HSV prophylaxis is recommended in VZV seropositive patients. ${ }^{12}$ \\
\hline & PCP prophylaxis is recommended in patients receiving concomitant glucocorticoids and elotuzumab. ${ }^{12}$ \\
\hline \multirow[t]{3}{*}{ CCR4-targeted agent } & PCP prophylaxis is recommended in patients on mogamulizumab. ${ }^{12}$ \\
\hline & HSV prophylaxis is recommended in patients on mogamulizumab. ${ }^{12}$ \\
\hline & $\begin{array}{l}\text { Tenofovir or entecavir is recommended in } \mathrm{HBs} \text { Ag positive patients who are candidates for treatment with } \\
\text { mogamulizumab. }{ }^{12} \\
\text { HBV viral load should be monitored in HBs Ag-negative/anti-HBc-positive patients who are candidates for } \\
\text { treatment with mogamulizumab. } \\
\text { Prophylaxis with lamivudine could be considered in HBs Ag negative and anti-HBc-positive patients. }{ }^{12}\end{array}$ \\
\hline
\end{tabular}


Table 3 (Continued).

\begin{tabular}{|c|c|}
\hline \multirow[t]{3}{*}{ Anti-CD20 monoclonal antibodies } & 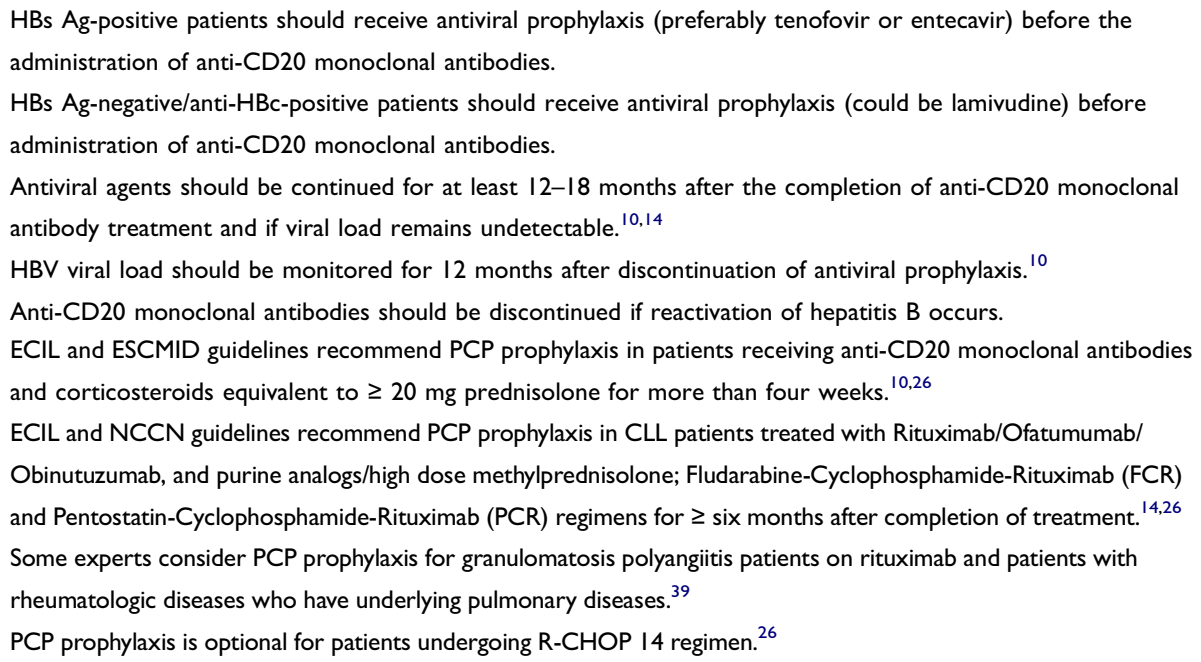 \\
\hline & $\begin{array}{l}\text { The third international consensus on CMV prophylaxis in solid organ transplant weakly recommends CMV } \\
\text { prophylaxis in donor/recipient seropositive patients who are candidates for rituximab therapy during treatment of } \\
\text { solid organ transplant rejection or desensitization protocol for up to } 6 \text { months. }{ }^{15}\end{array}$ \\
\hline & $\begin{array}{l}\text { Antiviral prophylaxis against HSV and VZV is recommended in CLL patients during therapy with Rituximab/ } \\
\text { Ofatumumab/Obinutuzumab, and fludarabine/high dose methylprednisolone; Fludarabine-Rituximab (FR), } \\
\text { Fludarabine-Cyclophosphamide-Rituximab (FCR) and Pentostatin-Cyclophosphamide-Rituximab (PCR) for 6-12 } \\
\text { months after discontinuation of the chemotherapy regimen. }{ }^{87}\end{array}$ \\
\hline \multirow[t]{4}{*}{ Anti-CD52 monoclonal antibody } & $\begin{array}{l}\text { In the case of latent tuberculosis patients undergoing alemtuzumab therapy, concomitant treatment with isoniazid } \\
\text { for nine months, rifampin for four months, or the combination of isoniazid and rifampin for three months is } \\
\text { recommended. }{ }^{10}\end{array}$ \\
\hline & $\begin{array}{l}\text { In the case of latent tuberculosis, tenofovir or entecavir is recommended in all } \mathrm{HBs} \text { Ag positive patients who are } \\
\text { candidates for treatment with alemtuzumab. } \\
\text { Antiviral agents should be continued for at least } 6-12 \text { months after the last dose of alemtuzumab. }{ }^{10} \\
\mathrm{HBV} \text { viral load should be monitored in } \mathrm{HBs} \mathrm{Ag} \text {-negative and anti-HBc positive patients who are candidates for treatment } \\
\text { with alemtuzumab. Prophylaxis with lamivudine could be considered in HBs Ag negative and Anti HBc-positive patients. }{ }^{10}\end{array}$ \\
\hline & $\begin{array}{l}\text { PCP prophylaxis is recommended in patients treated with alemtuzumab for hematologic malignancies and indications } \\
\text { other than multiple sclerosis for at least } 2-6 \text { months and should be continued until } \mathrm{CD}_{4}{ }^{+} \geq 200 \text { cells } / \mu \mathrm{L}^{26} \\
\mathrm{PCP} \text { infection associated with alemtuzumab used in multiple sclerosis is extremely rare, and prophylaxis is not routinely } \\
\text { recommended. }{ }^{64} \\
\text { If alemtuzumab is administered for solid organ transplantation induction, the American Society of Transplant recommends } \\
\text { PCP prophylaxis for at least } 6-12 \text { months after induction. Life long duration of PCP prophylaxis may be considered for lung } \\
\text { and small bowel transplant or patients with chronic CMV infection or prior history of PCP infection. }{ }^{17} \\
\text { If alemtuzumab is administered for conditioning of allogeneic hematopoietic stem cell transplantation, PCP prophylaxis is } \\
\text { recommended for at least six months. }{ }^{14}\end{array}$ \\
\hline & $\begin{array}{l}\text { CMV prophylaxis should be considered in hematologic malignancies with the initiation of each cycle of } \\
\text { alemtuzumab therapy and continued for at least two months until } C D 4^{+} \geq 200 \text { cells/ } \mu \mathrm{L}^{14} \\
\text { If alemtuzumab is administered for solid organ transplantation induction, the third international consensus on } \\
\mathrm{CMV} \text { in solid organ transplant recommends } \mathrm{CMV} \text { prophylaxis for six months in CMV IgG Donor+/Recipients } \pm \text { for } \\
\text { kidney transplants, } 3-6 \text { months for liver, heart, pancreas recipients and } 6-12 \text { months for lung recipients. }{ }^{15} \\
\text { CMV prophylaxis is not currently required in multiple sclerosis patients; CMV DNAemia testing is recommended } \\
\text { in the presence of signs and symptoms of mononucleosis. Some experts recommend weekly monitoring of CMV- } \\
\text { DNAemia for the first month after initiating alemtuzumab. }{ }^{64}\end{array}$ \\
\hline
\end{tabular}

(Continued) 
Table 3 (Continued).

\begin{tabular}{|c|c|}
\hline & $\begin{array}{l}\text { If alemtuzumab is administered for induction of allogeneic hematopoietic stem cell transplantation, VZV prophylaxis is } \\
\text { recommended for one year. }{ }^{14} \\
\mathrm{HSV} \text { prophylaxis should be considered in hematologic malignancies and other off-label indications with the initiation of } \\
\text { each cycle of alemtuzumab therapy and continued for at least two months until } \mathrm{CD} 4^{+} \geq 200 \mathrm{cells} / \mu \mathrm{L}^{10.14} \\
\mathrm{HSV} \text { prophylaxis should be considered in multiple sclerosis patients with the initiation of each cycle of alemtuzumab } \\
\text { therapy and continued for at least two months until CD4 }{ }^{+} \geq 200 \text { cells/ } \mu \mathrm{L}^{14,64} \\
\text { If alemtuzumab is administered for solid organ transplantation induction immunosuppressive therapy, HSV/VZV } \\
\text { prophylaxis is recommended in CMV IgG Donor-/Recipient- (low-risk CMV) transplants. }{ }^{15}\end{array}$ \\
\hline & Listeria- and toxoplasma-free diet should be recommended in patients under alemtuzumab therapy. ${ }^{10}$ \\
\hline \multirow[t]{2}{*}{ T-Cell Co-stimulation Blocker } & $\begin{array}{l}\text { Antiviral treatment is recommended in } \mathrm{HBs} \text { Ag- positive patients who are candidates for abatacept therapy. }{ }^{30} \\
\text { Monitoring of } \mathrm{HBV} \text { viral load is recommended in HBsAg-negative and anti-HBc- positive patients. }{ }^{30}\end{array}$ \\
\hline & $\begin{array}{l}\text { Some experts consider PCP prophylaxis for patients with rheumatologic diseases under abatacept who have } \\
\text { underlying pulmonary diseases or receiving } \geq 15 \mathrm{mg} / \text { day prednisolone for more than four weeks. }{ }^{39}\end{array}$ \\
\hline Agent targeting B-cell activating factor & $\begin{array}{l}\text { Some experts consider PCP prophylaxis for patients with rheumatologic diseases under abatacept who have } \\
\text { underlying pulmonary diseases or receiving } \geq 15 \mathrm{mg} / \text { day prednisolone for more than four weeks. }{ }^{39}\end{array}$ \\
\hline lgE-targeted agent & $\begin{array}{l}\text { In the case of parasitic infections, patients should be treated with a specific antiparasitic agent prior to omalizumab } \\
\text { administration. }{ }^{8}\end{array}$ \\
\hline IL-5-targeted agents & $\begin{array}{l}\text { Some experts recommend PCP prophylaxis in Eosinophilic Granulomatosis with Polyangiitis (EGPA) patients on } \\
\text { IL-5 targeted agents. }{ }^{39}\end{array}$ \\
\hline \multirow[t]{3}{*}{ IL-12 and IL-23-targeted agent } & $\begin{array}{l}\text { In the case of latent tuberculosis, treatment with isoniazid for nine months, rifampin for four months, or the } \\
\text { combination of isoniazid and rifampin for three months could be considered. }\end{array}$ \\
\hline & $\begin{array}{l}\text { Antiviral treatment is recommended in HBS-Ag positive patients who are candidates for ustekinumab therapy. } \\
\text { Monitoring of HBV viral load is recommended in HBS-Ag negative and HBV-Ab positive patients. }{ }^{8}\end{array}$ \\
\hline & $\begin{array}{l}\text { Some experts consider PCP prophylaxis in rheumatologic disease patients on ustekinumab who have underlying } \\
\text { pulmonary diseases or receiving } \geq 15 \mathrm{mg} / \text { day prednisolone for more than four weeks. }{ }^{39}\end{array}$ \\
\hline \multirow[t]{2}{*}{ IL-17-targeted agents } & $\begin{array}{l}\text { In the case of latent tuberculosis, treatment with isoniazid for nine months, rifampin for four months, or the } \\
\text { combination of isoniazid and rifampin for three months could be considered. }{ }^{8}\end{array}$ \\
\hline & $\begin{array}{l}\text { Some experts consider PCP prophylaxis in rheumatologic disease patients on secukinumab who have underlying } \\
\text { pulmonary diseases or receiving } \geq 15 \mathrm{mg} / \text { day prednisolone for more than four weeks. }{ }^{39}\end{array}$ \\
\hline \multirow[t]{2}{*}{ Component 5 (C5)-targeted agents } & $\begin{array}{l}\text { Ciprofloxacin } 500 \mathrm{mg} \text { Bid or penicillin } \vee 250 \mathrm{mg} \text { Bid orally should be administered for at least four weeks after } \\
\text { completion of vaccination preferably until antibody titer reaches protective. }{ }^{8}\end{array}$ \\
\hline & $\begin{array}{l}\text { The third international consensus on } \mathrm{CMV} \text { in solid organ transplant weakly recommends CMV prophylaxis in } \\
\text { donor/recipient seropositive patients who are candidates for eculizumab therapy during and up to } 6 \text { months after } \\
\text { treatment of solid organ transplant rejection. }{ }^{15}\end{array}$ \\
\hline \multirow[t]{3}{*}{ IL-6-targeted agents } & $\begin{array}{l}\text { In the case of latent tuberculosis, treatment with isoniazid for nine months, rifampin for four months, or the } \\
\text { combination of isoniazid and rifampin for three months could be considered. }{ }^{8}\end{array}$ \\
\hline & $\begin{array}{l}\text { Antiviral treatment is recommended in } \mathrm{HBsAg} \text { positive patients who are candidates for IL- } 6 \text { targeted agents. } \\
\text { Monitoring of } \mathrm{HBV} \text { viral load is recommended in } \mathrm{HBs} \mathrm{Ag} \text {-negative/anti-HBc positive patients. }\end{array}$ \\
\hline & $\begin{array}{l}\text { Some experts recommend consideration of PCP prophylaxis in rheumatologic disease patients on tocilizumab } \\
\text { who have underlying pulmonary diseases or receiving } \geq 15 \mathrm{mg} / \text { day prednisolone for more than four weeks. }\end{array}$ \\
\hline \multirow[t]{2}{*}{ Proteasome inhibitors } & HSV/VZV prophylaxis is recommended in VZV seropositive patients at least four weeks after discontinuation of therapy." \\
\hline & PCP prophylaxis could be considered in multiple myeloma patients treated with high dose corticosteroids." \\
\hline
\end{tabular}

(Continued) 
Table 3 (Continued).

\begin{tabular}{|c|c|}
\hline & $\begin{array}{l}\text { The third international consensus on CMV prophylaxis in solid organ transplant weakly recommends CMV } \\
\text { prophylaxis in donor/recipient seropositive patients who are candidates for bortezomib therapy during treatment } \\
\text { of solid organ transplant rejection or desensitization protocol and up to } 6 \text { months later. }{ }^{15}\end{array}$ \\
\hline \multirow[t]{3}{*}{$\begin{array}{l}\text { Agents targeting PD-I/PD-LI and agents } \\
\text { targeting CTLA-4 }\end{array}$} & $\begin{array}{l}\text { Autoimmune manifestations of PD-I/PD-LI targeted and CTLA-4 blockade agents may require treatment with } \\
\text { corticosteroids or TNF inhibitors. ECIL and ESCMID experts recommend PCP prophylaxis in patients treated } \\
\text { with corticosteroids equivalent to } \geq 20 \mathrm{mg} \text { prednisolone for more than four weeks. }{ }^{11,88} \\
\text { The Society for Immunotherapy of Cancer recommends PCP prophylaxis in patients treated with corticosteroids } \\
\text { equivalent to } \geq 30 \mathrm{mg} \text { prednisolone for more than three weeks. }{ }^{88}\end{array}$ \\
\hline & $\begin{array}{l}\text { In the case of latent tuberculosis, treatment with isoniazid or rifampin is recommended in patients treated } \\
\text { with anti-PD- I/CTLA-4 blocking agents and TNF inhibitors. Antiviral prophylaxis against hepatitis B is } \\
\text { recommended if necessary in patients treated with anti-PD-I and TNF inhibitors." }\end{array}$ \\
\hline & $\begin{array}{l}\text { Antiviral prophylaxis against hepatitis B is recommended if necessary in patients treated with anti-PD- I/CTLA-4 } \\
\text { blocking agents and TNF inhibitors." }\end{array}$ \\
\hline $\begin{array}{l}\text { BCR-ABL } \\
\text { Tyrosine kinase inhibitors }\end{array}$ & $\begin{array}{l}\text { Antiviral agent against hepatitis } B \text { is recommended for HBV infected HBs Ag-positive before administration of } \\
\text { BCR-ABL tyrosine kinase inhibitors. } \\
\text { HBV viral load should be monitored in HBs Ag-negative/anti-HBc-positive patients who are candidates for } \\
\text { treatment with BCR-ABL tyrosine kinase inhibitors. }\end{array}$ \\
\hline \multirow[t]{2}{*}{ mTOR inhibitors } & $\begin{array}{l}\text { In the case of latent tuberculosis, treatment with isoniazid for nine months, rifampin for four months, or the } \\
\text { combination of isoniazid and rifampin for three months could be considered. }{ }^{9}\end{array}$ \\
\hline & Antiviral agents could be considered in chronic HBV-infected patients. ${ }^{9}$ \\
\hline \multirow[t]{3}{*}{ JAK inhibitors } & $\begin{array}{l}\text { In the case of latent tuberculosis, treatment with isoniazid for nine months, rifampin for four months, or the } \\
\text { combination of isoniazid and rifampin for three months should be considered. }\end{array}$ \\
\hline & $\begin{array}{l}\text { Antiviral prophylaxis is recommended in HBS-Ag positive patients. }{ }^{9} \\
\text { Monitoring of viral load is recommended in HBsAg-negative/anti-HBc-positive patients. }\end{array}$ \\
\hline & $\begin{array}{l}\text { PCP prophylaxis could be considered in patients receiving a high dose of JAK inhibitors, and concomitant } \\
\text { corticosteroid therapy, and lymphopenic patients. }\end{array}$ \\
\hline $\begin{array}{l}\text { Sphingosine I-phosphate receptor } \\
\text { modulator }\end{array}$ & $\begin{array}{l}\text { Acyclovir/Valacyclovir prophylaxis could be considered for patients treated with corticosteroid pulse beyond } 3-5 \\
\text { days and fingolimod. }{ }^{63}\end{array}$ \\
\hline Bruton Tyrosine kinase inhibitors & $\begin{array}{l}\text { PCP prophylaxis is recommended in CLL patients treated with ibrutinib in the presence of additional risk factors, } \\
\text { including concomitant fludarabine or high dose corticosteroid therapy. }{ }^{9,87}\end{array}$ \\
\hline Phosphatidylinositol-3-kinase inhibitors & $\begin{array}{l}\text { PCP prophylaxis is recommended in CLL patients who are candidates for idelalisib therapy up to } 2-6 \text { months after } \\
\text { discontinuation. }\end{array}$ \\
\hline Monoclonal antibody targeting CD25 & 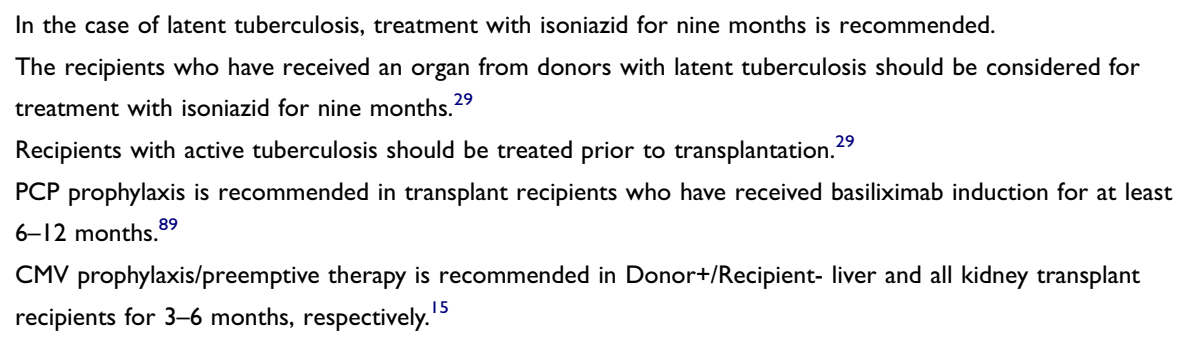 \\
\hline
\end{tabular}

Abbreviations: CLL, chronic lymphocytic leukemia; CMV, cytomegalovirus; ECIL, European conference on infections in leukemia; ESCMID, European Society of Clinical Microbiology and Infectious Diseases; IgE, Immunoglobulin E; IgG, Immunoglobulin G; IL-I, interleukin-I; IL-5, interleukin-5; IL-6, interleukin-6; IL-I2, interleukin- I2; IL17, interleukin- 17; IL-23, interleukin-23; HBs Ag, hepatitis B surface antigen; HBV, hepatitis B virus; HSV, Herpes simplex virus; JAK, Janus kinase; mTOR, mammalian target of rapamycin; NCCN, National Comprehensive Cancer Network, PCP, Pneumocystis carinii pneumonia; PCR, Polymerase chain reaction; PDI, programmed death I; PD-LI, Programmed death-ligand I; R-CHOP, rituximab, cyclophosphamide, hydroxydaunorubicin hydrochloride (doxorubicin hydrochloride), vincristine; TNF, tumor necrosis factor; VZV, varicella-zoster virus. 
Table 4 Evidence and Recommendations on Monitoring of Patients on Biologic and Targeted Immunomodulatory Therapies

\begin{tabular}{|c|c|}
\hline CDI9-targeted agents & $\begin{array}{l}\text { Risk of neutropenia: } C B C \text { monitoring is recommended }{ }^{10} \\
\text { If neurologic or cognitive impairment occurred, MRI should be considered, and CSF for JC virus DNA PCR should } \\
\text { be tested. }{ }^{10} \\
\text { Monitoring for signs and symptoms of catheter-related infections should be considered in patients receiving blinatumomab. }{ }^{10}\end{array}$ \\
\hline CD30-targeted agents & $\begin{array}{l}\text { Risk of neutropenia: CBC monitoring is recommended. }{ }^{12} \\
\text { If neurologic or cognitive impairment occurred, MRI should be considered and CSF for JC virus DNA PCR should be } \\
\text { tested. }{ }^{12} \\
\text { Regular monitoring of CMV PCR and signs and symptoms of CMV disease is recommended in patients on brentuximab } \\
\text { vedotin. }{ }^{12}\end{array}$ \\
\hline CD38-targeted agents & Risk of neutropenia: $C B C$ monitoring is recommended. ${ }^{12}$ \\
\hline CD40-targeted agents & Risk of neutropenia: $\mathrm{CBC}$ monitoring is recommended. ${ }^{12}$ \\
\hline CD319-targeted agents & Risk of lymphopenia: $C B C$ monitoring is recommended. ${ }^{12}$ \\
\hline CCR4-targeted agents & $\begin{array}{l}\text { Monitoring of lymphocyte count is recommended. }{ }^{12} \\
\text { Regular monitoring of CMV PCR and signs and symptoms of CMV disease is recommended in patients on mogamulizumab. }{ }^{12}\end{array}$ \\
\hline Anti-CD20 monoclonal antibodies & $\begin{array}{l}\text { If neurologic or cognitive impairment occurs, MRI should be considered, and CSF for JC virus DNA PCR should be tested. } \\
\text { Monitor immunoglobulin levels during treatment with anti-CD20 monoclonal antibodies. }{ }^{22,90} \\
\text { Immunoglobulin levels are best to be monitored every } 6-12 \text { months and at least up to I year after discontinuation of } \\
\text { rituximab. } \\
\text { Long term monitoring of lgG levels in patients with bronchiectasis or those treated with immunosuppressive agents is } \\
\text { reasonable. }{ }^{22} \\
\text { Immunoglobulin replacement therapy with } 0.4 \mathrm{~g} / \mathrm{kg} / \text { month (SC or IV) could be considered in case of persistent infections } \\
\text { associated with low IgG level; in patients with low } \mathrm{lgG} \text { level and concomitant comorbidities (neutropenia, bronchiectasis) or } \\
\text { concomitant use of immunosuppressive agents, including corticosteroids. }{ }^{22} \\
\text { Late-onset neutropenia episodes are mostly mild and do not predispose patients to infections as much as } \\
\text { hypogammaglobulinemia. }{ }^{91,92} \\
\text { The optimal approach in patients with a history of late-onset neutropenia is unclear; however, re-treatment with rituximab } \\
\text { has been safe in most cases. }{ }^{92} \\
\text { The role of GCSF in anti-CD20 associated neutropenia is not clearly defined; the decision should be made on a case-by-case } \\
\text { basis. }{ }^{91} \\
\text { Limited data have demonstrated the occurrence of late-onset neutropenia with other anti-CD20 therapies including } \\
\text { obinutuzumab, ofatumumab, and ocrelizumab. }{ }^{93}\end{array}$ \\
\hline T-Cell Co-stimulation blocker & $\begin{array}{l}\text { Brain MRI and CSF analysis for JCV PCR should be obtained if neurologic impairment (visual disturbance, } \\
\text { progressive paresis, cognitive impairment) occurs. }{ }^{42}\end{array}$ \\
\hline $\begin{array}{l}\text { Agent targeting B-cell activating factor } \\
\text { (BAFF, BLyS) }\end{array}$ & $\begin{array}{l}\text { Brain MRI and CSF analysis for JCV PCR should be obtained if neurologic impairment (visual disturbance, } \\
\text { progressive paresis, cognitive impairment) occurs. }{ }^{42}\end{array}$ \\
\hline $\begin{array}{l}\text { Monoclonal antibody targeting } \alpha 4- \\
\text { integrin and CD I/ a }\end{array}$ & $\begin{array}{l}\text { After the completion of the first year of therapy, JCV PCR should be tested every three months in JCV-seronegative } \\
\text { patients treated with natalizumab. }{ }^{\prime \prime} \\
\text { JCV PCR should be tested every six months in JCV-seropositive patients with lgG antibody index } \leq 1.5 .^{. "} \\
\text { The risks versus benefits of therapy should be considered in JCV seropositive patients with IgG antibody index } \geq 1.5 \\
\text { and JCV seropositive patients who have received natalizumab for more than } 48 \text { weeks. } \\
\text { For the early diagnosis of PML, the high sensitive assay should be utilized to detect JCV DNA. Negative CSF JCV } \\
\text { PCR does not exclude PML even in repeated lumbar punctures. }{ }^{44} \\
\text { Monitoring of signs and symptoms of PML (ataxia, dysarthria, motor weakness, and cognitive impairment) should be } \\
\text { considered for at least six months after discontinuation of natalizumab. }{ }^{\prime \prime} \\
\text { Brain MRI and CSF analysis for JCV PCR should be obtained if neurologic impairment (visual disturbance, } \\
\text { progressive paresis, cognitive impairment) occurs. } \\
\text { Natalizumab should be discontinued if PML develops. }{ }^{\prime \prime} \\
\text { No cases of PML have been observed with vedolizumab in the clinical trials so far. }{ }^{42}\end{array}$ \\
\hline
\end{tabular}


Table 4 (Continued).

\begin{tabular}{|c|c|}
\hline Component 5 (C5) targeted agent & $\begin{array}{l}\text { Patients treated with eculizumab should be monitored for signs and symptoms of meningococcal disease (headache, } \\
\text { nausea, vomiting, fever, rash, confusion, flu-like symptoms, photophobia, arthralgia, tenosynovitis). }{ }^{8}\end{array}$ \\
\hline $\begin{array}{l}\text { BCR-ABL } \\
\text { tyrosine kinase Inhibitors }\end{array}$ & Weekly CMV PCR could be considered for HSCT patients on dasatinib. ${ }^{9}$ \\
\hline JAK inhibitors & $\begin{array}{l}\text { Lymphocyte and neutrophil count should be monitored while treatment with tofacitinib; discontinue tofacitinib if } \\
\text { lymphocyte count }<500 \text { cells } / \mathrm{mm}^{3} \text { or ANC }<500 \text { cells } / \mathrm{mm}^{3.94} \\
\text { Neutrophil count should be monitored while treatment with ruxolitinib. Interrupt treatment with ruxolitinib if ANC } \\
<500 \text { cells } / \mathrm{mm}^{3.95} \\
\text { Monitor for signs and symptoms of HSV infections. } \\
\text { In case of mild Herpes Zoster infection in inflammatory bowel disease patients, some experts recommend holding } \\
\text { tofacitinib until resolution of infection; in disseminated Herpes Zoster infections, alternative therapies could be } \\
\text { considered. }\end{array}$ \\
\hline $\begin{array}{l}\text { Sphingosine I-phosphate receptor } \\
\text { modulator }\end{array}$ & $\begin{array}{l}\text { CBC should be monitored during therapy. } \\
\text { Fingolimod should be interrupted in patients with absolute lymphocyte count }<0.2 * 10^{9} / 1 .{ }^{97} \\
\text { Cases of cryptococcal meningitis and PML have been reported in patients receiving fingolimod. } \\
\text { Monitor for signs and symptoms (ataxia, dysarthria, motor weakness, cognitive impairment, headache, } \\
\text { photosensitivity, and personality changes). }{ }^{11} \\
\text { Screening for pap smear abnormalities could be considered during treatment with fingolimod. }{ }^{97}\end{array}$ \\
\hline Bruton Tyrosine kinase inhibitors & $\begin{array}{l}\text { If neurologic or cognitive impairment occurs during treatment with ibrutinib, MRI should be considered and CSF for } \\
\text { JC virus DNA PCR should be tested. }{ }^{9}\end{array}$ \\
\hline Phosphatidylinositol-3-kinase inhibitors & $\begin{array}{l}\text { Monitoring for CMV PCR is recommended in seropositive patients on idelalisib. } \\
\text { If signs and symptoms of CMV disease (leukopenia, thrombocytopenia, colitis, pneumonitis, nausea, vomiting, } \\
\text { diarrhea, or abdominal pain) occurred during treatment with an idelalisib, check for CMV PCR. } \\
\text { Idelalisib should be discontinued in case of severe diarrhea, significant elevations in hepatic enzymes, or } \\
\text { pneumonitis. }\end{array}$ \\
\hline
\end{tabular}

Abbreviations: ANC, absolute neutrophil count; BAFF, B-cell activating factor; BLyS, B Lymphocyte Stimulator; CBC, complete blood cells; CSF, cerebrospinal fluid; CMV, cytomegalvirus; GCSF, Granulocyte-colony stimulating factor; HSCT, Hematopoietic stem cell transplantation; MRI, magnetic resonance imaging; JCV, John Cunningham virus; PCR, polymerase chain reaction; PML, progressive multifocal leukoencephalopathy.

5 cases with ocrelizumab); however, most of these cases could be attributed to previous natalizumab or fingolimod therapy. Therefore, it is reasonable to monitor MRI for signs and symptoms of PML (e.g., visual disturbance, progressive paresis, cognitive impairment) when switching from either natalizumab or fingolimod to anti-CD20 therapies. ${ }^{47}$ Currently, there is no standard and specific therapy for PML. The offending agent should be discontinued permanently. Plasma exchange (e.g., 3-5 exchanges over 5 to 8 days) has been used for the reversal of natalizumab-associated PML. However, this modality often leads to immune reconstitution inflammatory syndrome (IRIS) phenomenon, which is a neurological deterioration associated with brain swelling and risk of herniation. ${ }^{48}$

\section{The Risk of Latent Tuberculosis}

Rheumatoid arthritis itself is associated with increased risk of tuberculosis reactivation up to 3.17 times. In patients with rheumatoid arthritis treated with TNF inhibitors, the risk is increased up to 17 fold than the general population. ${ }^{49}$ When compared with etanercept, other anti-TNF monoclonal antibodies are associated with a statistically significant higher risk of tuberculosis reactivation. Ai et al. demonstrated that the risk of tuberculosis reactivation with adalimumab and infliximab is 3.88 and 2.78 times more than etanercept, respectively. The effect of anti-TNF monoclonal antibodies on inducing T-cell apoptosis, complementdependent cytotoxicity, and pharmacokinetic properties could explain the higher potential of adalimumab and infliximab over etanercept in reactivating latent tuberculosis. ${ }^{19,50}$ Statistical difference between infliximab and adalimumab has not been found; however, the risk of latent tuberculosis reactivation with infliximab was 1.28 times more than adalimumab. ${ }^{49}$ Another meta-analysis showed that the incidence rate of 
Table 5 Evidence and Recommendations on Immunization of Patients on Biologic and Targeted Immunomodulatory Therapies

\begin{tabular}{|c|c|}
\hline TNF inhibitors & $\begin{array}{l}\text { Immunization with inactivated vaccines during therapy with TNF inhibitors is recommended. }{ }^{98} \\
\text { Non-immunized patients who were at risk should ideally complete the HBV vaccine series } \geq \text { two weeks prior to } \\
\text { the initiation of TNF inhibitors. }{ }^{16} \\
\text { The EMA label of TNF inhibitors recommends that infants born from mothers on TNF inhibitors receive live vaccines } \\
\text { after } \geq \text { five months of last adalimumab injection, }{ }^{99} \geq \text { four months of last etanercept injection, }{ }^{100} \geq \text { six months of last } \\
\text { golimumab injection, }{ }^{101} \geq \text { five months after certolizumab injection }{ }^{102} \text { and } \geq \text { six months after birth in infliximab treated } \\
\text { mothers } ;{ }^{66} \text { however, vaccine response to Haemophilus influenzae in infants born from mothers on biologic therapies } \\
\text { including infliximab, adalimumab, certolizumab pegol, and golimumab is not impaired. } \\
\text { The Canadian Dermatology Association strongly recommends routine immunization schedule for infants exposed to } \\
\text { biologic agents during pregnancy and lactation. }{ }^{103} \\
\text { EULAR recommends that live attenuated vaccines should be avoided during the first six months of life in newborns } \\
\text { exposed to TNF inhibitors after } 22 \text { weeks of gestation. }{ }^{98}\end{array}$ \\
\hline IL-I-targeted agents & $\begin{array}{l}\text { In patients receiving IL-I targeted agents, vaccination against Pneumococcus and Haemophilus influenzae type B } \\
\text { should be considered. } \\
\text { Infants born from mothers on canakinumab could receive live vaccines after } \geq 16 \text { weeks of the last injection. }{ }^{68} \text { If a } \\
\text { live vaccine is required; patients on rilonacept could be vaccinated } \geq \text { six weeks of the last dose and } \geq \text { six weeks } \\
\text { before the next dose. }{ }^{104}\end{array}$ \\
\hline CDI9-targeted agents & $\begin{array}{l}\text { The recommendations on vaccination with anti-CD20 therapies could be extrapolated to anti-CDI9 targeted } \\
\text { agents such as blinatumomab. }{ }^{28} \\
\text { Live vaccines for infants born from mothers on CDI } 9 \text { targeted agents should be postponed until B cell recovery. }{ }^{105}\end{array}$ \\
\hline Anti-CD20 monoclonal antibodies & 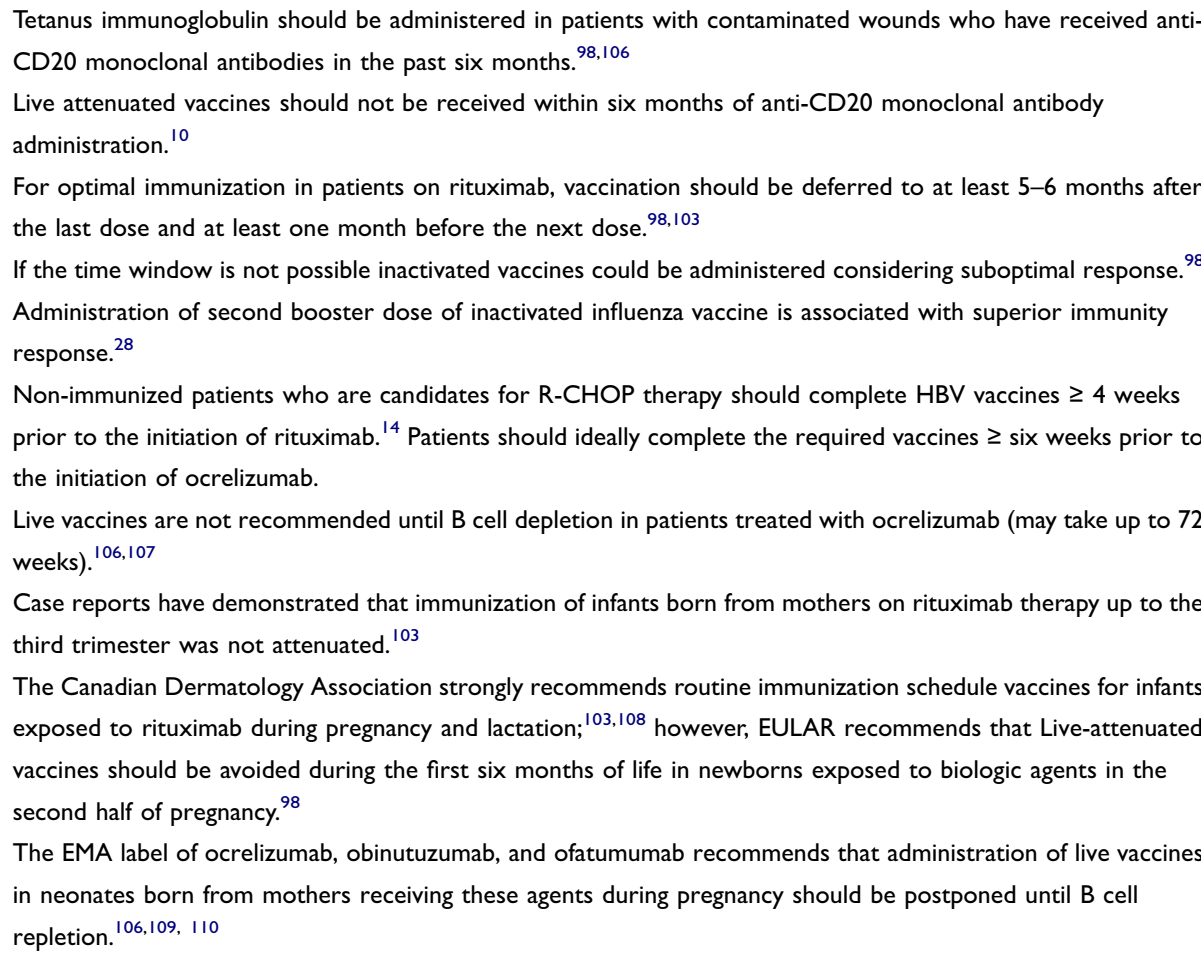 \\
\hline Anti-CD52 monoclonal antibodies & $\begin{array}{l}\text { Live vaccines should be avoided up to at least } 12 \text { months after discontinuation of MabCampath }{ }^{\circledR} .111 \\
\text { Poor response to vaccination is observed in patients with hematologic malignancies who have received } \\
\text { alemtuzumab in the previous six months. }{ }^{77} \\
\text { Immunization requirements should be completed } \geq 6 \text { weeks prior to the initiation of Lemtrada }{ }^{\circledR} \text {. } \\
\text { VZV seronegative patients should be immunized } \geq \text { six weeks prior to the initiation of Lemtrada }{ }^{\circledR 7}{ }^{76}\end{array}$ \\
\hline T-Cell Co-stimulation blockers & Live vaccines could be administered $\geq 3$ months after discontinuation of abatacept. ${ }^{1 / 2}$ \\
\hline
\end{tabular}


Table 5 (Continued).

\begin{tabular}{|c|c|}
\hline $\begin{array}{l}\text { Monoclonal antibodies targeting } \alpha 4- \\
\text { integrin and CD I la }\end{array}$ & $\begin{array}{l}\text { The EMA label recommends discontinuation of efalizumab eight weeks prior to vaccination and resumption of } \\
\text { therapy two weeks after vaccination. }{ }^{78} \\
\text { Routine immunization schedule, including inactivated and live vaccines for infants exposed to natalizumab during } \\
\text { pregnancy and lactation, could be considered. }{ }^{103} \\
\text { Vaccine response to Haemophilus influenzae in infants born from mothers on natalizumab was not impaired. }\end{array}$ \\
\hline IL-I 2 and IL-23-targeted agent & $\begin{array}{l}\text { Live vaccines could be administered } \geq 15 \text { weeks after discontinuation of ustekinumab. }{ }^{113} \\
\text { Vaccine response to Haemophilus influenzae in infants born from mothers on ustekinumab was not impaired. } \\
\text { The Canadian Dermatology Association strongly recommends routine immunization schedule, including both } \\
\text { inactivated and live vaccines for infants exposed to ustekinumab during pregnancy and lactation. }{ }^{103}\end{array}$ \\
\hline Component 5 (C5)-targeted agents & $\begin{array}{l}\text { Unvaccinated patients should receive } S \text {. pneumonia and } H \text {. influenzae type } b \text { vaccine } \geq 2 \text { weeks prior to treatment } \\
\text { with eculizumab. } \\
\text { Two-dose series with quadrivalent conjugate (MenACWY) at least two months apart and serogroup B (MenB) } \\
\text { either two-dose series at least a month apart or three-dose series at } 0, I, 2 \text { and } 6 \text { months should be administered. } \\
\text { Meningococcal immunization should be completed } \geq 2-4 \text { weeks prior to eculizumab administration. } \\
\text { Booster doses of tetravalent conjugate vaccine should be repeated every five years based on the duration of } \\
\text { therapy. }\end{array}$ \\
\hline Proteasome Inhibitors & $\begin{array}{l}\text { VZV seronegative patients should receive live attenuated vaccine } \geq \text { I month prior to initiation of therapy." } \\
\text { HSV subunit vaccine could be considered for VZV seropositive patients } \geq 50 \text { years." }\end{array}$ \\
\hline $\begin{array}{l}\text { BCR-ABL } \\
\text { Tyrosine kinase inhibitors }\end{array}$ & $\begin{array}{l}\text { ECIL guidelines recommend yearly seasonal influenza vaccine and PCV followed by PPSV } 23 \text { ( } 8 \text { weeks later) in } \\
C M L \text { patients on BCR-ABL tyrosine kinase inhibitors. }{ }^{23}\end{array}$ \\
\hline JAK inhibitors & $\begin{array}{l}\text { Vaccination with Shingrix }{ }^{\circledR} \text { should be considered } \geq 2 \text { weeks or }\left(\text { Zostavax }^{\circledR} \geq 4 \text { weeks) prior to the initiation of }\right. \\
\text { tofacitinib. }{ }^{94}\end{array}$ \\
\hline $\begin{array}{l}\text { Sphingosine I-phosphate receptor } \\
\text { modulators }\end{array}$ & $\begin{array}{l}\text { Live vaccines are not recommended until at least two months after discontinuation of fingolimod. }{ }^{97} \\
\text { The EMA label recommends vaccination against } \mathrm{HPV} \text { prior to the initiation of fingolimod. }{ }^{97} \\
\text { VZV seronegative, non-immunized patients should receive live attenuated ( } 2 \text { doses of Varivax }{ }^{\circledR} \text { separated by four } \\
\text { weeks) } \geq \text { I month prior to initiation of therapy. }{ }^{11,63} \\
\text { Adjuvant herpes zoster subunit }\left(\mathrm{HZ} / \mathrm{su} \text { ) vaccine could be considered for VZV seropositive patients } \geq 50 \text { years. }{ }^{63}\right. \\
\text { The vaccine should not be administered while the patient is on antiviral agents against VZV. } \\
\text { An antiviral agent should be prescribed for vaccinated patients who develop rashes. }{ }^{63} \\
\text { When treated with pulse dose corticosteroid, vaccination should be postponed for at least one month after the } \\
\text { last dose of corticosteroid. }{ }^{63}\end{array}$ \\
\hline Bruton Tyrosine kinase inhibitors & Pneumococcal vaccine and yearly inactivated influenza vaccine is recommended in CLL patients. ${ }^{23}$ \\
\hline Monoclonal antibody targeting CD25 & $\begin{array}{l}\text { Inactivated vaccines could be administered } 3 \text { months after induction of basiliximab. } \\
\text { Inactivated influenza vaccine could be administered as early as one month after transplant. }{ }^{114}\end{array}$ \\
\hline
\end{tabular}

Abbreviations: CLL, Chronic lymphocytic leukemia; HBV, Hepatitis B virus; HPV, human papillomavirus; H. influenzae, Haemophilus influenza; ECIL, European Conference on Infections in Leukaemia; EMA, European medicines agency; EULAR; European league against rheumatism; IL-I, interleukin-I; S. pneumonia, Streptococcus pneumonia; TNF, tumor necrosis factor; VZV, varicella-zoster virus.

tuberculosis was highest with infliximab and certolizumab, followed by adalimumab, golimumab, tofacitinib, tocilizumab, etanercept, abatacept, and rituximab (44/ $9277 ; 13 / 4396 ; 30 / 12757 ; 4 / 3209 ; 11 / 6507 ; 9 / 12905 ; 3 /$ $7164 ; 2 / 7743$; and $2 / 11962$, respectively). ${ }^{51}$ The incidence of tuberculosis reactivation was similar in adalimumab- and golimumab-treated patients. ${ }^{51}$ It is noteworthy that the results could be affected by several confounding factors such as including patients from tuberculosis endemic areas in most of the certolizumab trials. The incidence rate of tuberculosis was 5-10 times more than the general population in North America and Western Europe (an incidence rate of 5-20 times were reported for anti-TNF therapies in 
these areas). A cohort study demonstrated that the risk of tuberculosis is higher with infliximab- and anakinratreated groups versus etanercept recipients (adjusted risk ratio: $1.6,1.3$, and 1.2 , respectively). ${ }^{52}$ Results of clinical trials have reported 10 cases of tuberculosis in 2588 ruxolitinib-treated patients. ${ }^{53}$ Limited reports of tuberculosis following ustekinumab therapy exist; however, no case of latent tuberculosis reactivation has been reported with secukinumab so far. ${ }^{54}$

The incidence of tuberculosis in kidney transplant recipients and multiple sclerosis patients treated with alemtuzumab was found to be $0.67 \%$ and $0.3 \%$, respectively; ${ }^{55}$ however, in a small study conducted in a high endemic area, the incidence of tuberculosis in patients with hematologic malignancies and autoimmune cytopenias was $31-45 \%{ }^{56}$ Few cases of tuberculosis reactivation have been reported in metastatic renal cell carcinoma patients receiving $\mathrm{mTOR}$ inhibitors, ${ }^{57,58}$ and in one case report in lung transplantation, reactivation of latent tuberculosis has been attributed to mTOR inhibitors. ${ }^{59}$

In summary, available data indicate that the risk of tuberculosis is greatest with monoclonal antibodies against TNF and alemtuzumab (because of insufficient data and diversities in sample size, we could not compare the risk) followed by JAK inhibitors and IL-1 targeted agents. Limited cases of reactivation of tuberculosis exist on mTOR inhibitors used in chemotherapy. The risk of tuberculosis reactivation with rituximab and tocilizumab was not more than the general population and appeared to be negligible. ${ }^{54}$ Accordingly, ESCMID recommends anti-TB prophylaxis in patients who are candidates to receive TNF inhibitors, alemtuzumab, JAK inhibitors, and mTOR inhibitors (used in chemotherapy regimens). Isoniazid for nine months, rifampin for four months, or the combination of isoniazid and rifampin for three months could be considered for the treatment of latent tuberculosis in the setting of biologic and targeted immunomodulators.

\section{The Risk of Herpes Simplex Virus (HSV) and Varicella-Zoster Virus (VZV) Infections}

Compared to the bortezomib-free regimens, the incidence of herpes zoster infection increased up to two-fold when bortezomib was added to the chemotherapeutic regimen of multiple myeloma patients $\left(11 \%\right.$ and $22.3 \%$, respectively). ${ }^{60}$ Tofacitinib-treated patients experienced HSV infection with an incidence rate of 4.4 per 100 patient-years and up to 7.7 per 100 patient-years in the Asian population versus 1.5 per 100 patient-years in rheumatoid arthritis patients receiving placebo. ${ }^{42,61}$ The incidence rates of HSV infection in patients with rheumatoid arthritis receiving TNF inhibitors and rituximab were 1.6 (golimumab) to 2.4 (certolizumab) and 2.2 per 100 patient-years, respectively. Incidence rates and hazard ratios were not statistically significant among TNF inhibitors and rituximab; glucocorticoids were associated with increased risk of infection. ${ }^{62}$

The graph represented by Arvin et al. in 2015 demonstrates comparative incidence of VZV infections associated with disease-modifying therapy of multiple sclerosis; the incidence of VZV infection is greatest with alemtuzumab $12 \mathrm{mg} /$ day (7-45 per 1000 patient-year) followed by fingolimod $0.5 \mathrm{mg}$ /day (6-17.5 per 1000 patient-year), natalizumab (8-16 per 1000 patient-year), and rituximab (8-13 per 1000 patient-year). ${ }^{63}$

ESCMID recommends HSV/VZV prophylaxis for proteasome inhibitors- and alemtuzumab-treated patients (for all their indications) and also considers HSV prophylaxis in fingolimod-treated patients that concurrently receive corticosteroid pulse therapy. Acyclovir/Valacyclovir could be taken into account as prophylaxis of HSV/VZV in susceptible patients discussed above. ${ }^{11}$

\section{The Risk of Cytomegalovirus (CMV) Infection}

Alemtuzumab is associated with a remarkable risk of CMV infection, particularly in hematologic malignancies and solid organ transplant recipients, and CMV prophylaxis is recommended in these populations. However, the risk of CMV infection in patients with multiple sclerosis treated with alemtuzumab is less than 1 per 100 patient-years. ${ }^{10}$ Therefore, ESCMID does not recommend CMV prophylaxis for multiple sclerosis patients on alemtuzumab. ${ }^{10,64}$ Dasatinib has been associated with CMV reactivation, particularly in post-HSCT patients (adjusted hazard ratio, 7.65; 95\% confidence interval, 1.84-31.7); ${ }^{9,65}$ and ESCMID recommends monitoring of $\mathrm{CMV}$ infection in these individuals. Besides dasatinib, regular monitoring of CMV PCR and signs as well as symptoms of CMV disease is also recommended for patients receiving mogamulizumab. ${ }^{12}$ Finally, the third international consensus on CMV in solid organ transplant weakly recommends CMV prophylaxis for donor/recipient seropositive patients who were candidates for either bortezomib or eculizumab therapy as treatment of solid organ transplant rejection or a part of desensitization 
protocol. ${ }^{15}$ Antiviral options for CMV prophylaxis include intravenous ganciclovir, oral valganciclovir, and high doses of oral valacyclovir. ${ }^{15}$

\section{Immunization in Patients on Biologic and Targeted Immunomodulators}

According to IDSA guidelines published in 2013, live vaccines, including measles, mumps, and rubella (MMR), live-attenuated influenza vaccine (LAIV), Bacillus Calmette-Guérin (BCG) vaccine, oral polio vaccine (OPV), live-attenuated HSV, and yellow fever should be avoided $\leq 2-4$ weeks before initiation and during treatment with immunosuppressants. ${ }^{16}$ The international guidelines recommend inactivated influenza, pneumococcal, toxoid tetanus, hepatitis A vaccine, hepatitis $B$, and human papillomavirus vaccines in patients with autoimmune rheumatologic diseases including those under biologic and targeted immunomodulators. ${ }^{18,20,21}$

The live-attenuated HSV vaccine should be preferably administered $\geq 4$ weeks prior to the initiation of immunosuppressive agents for high risk individuals including those older than 50 years. ACIP does not make any recommendations on the administration of recombinant Zoster vaccine (Shingrix ${ }^{\circledR}$ ) in highly-immunocompromised patients due to lack of data on efficacy and safety in this population; ${ }^{24,25}$ however, recombinant zoster vaccine, has demonstrated greater efficacy than live-attenuated HSV vaccine Zostavax $^{\circledR}$ ), decreases the risk of HZ in patients older than 70 years and also appears an interesting alternative to liveattenuated HSV vaccine in immunocompromised patients.

Humoral response to vaccine is generally not impaired in patients on TNF alpha inhibitors (except infliximab), ${ }^{66}$ anakinra, ${ }^{67}$ canakinumab, ${ }^{68}$ abatacept, ${ }^{69}$ belimumab, ${ }^{70}$ natalizumab, ${ }^{71}$ ustekinumab, ${ }^{72}$ IL-17-targeted agents, ${ }^{73}$ tocilizumab, ${ }^{74}$ probably proteasome inhibitors ${ }^{75}$ and alemtuzumab (in doses approved for multiple sclerosis). ${ }^{76}$ Meanwhile, immune response to vaccines is significantly decreased in patients receiving rituximab ${ }^{66}$ and alemtuzumab (used in hematologic malignancies). ${ }^{77}$ No data exist for immunization in patients under CD19 and CD22 targeted therapies; based on their impact on humoral immunity vaccine response is probably diminished during treatment with these agents. Immune response to vaccine may be attenuated in patients on efalizumab, ${ }^{78}$ BCR-ABL tyrosine kinase inhibitors, ${ }^{79}$ tofacitinib ${ }^{80}$ and ibrutinib. ${ }^{81}$ Patients treated with vedolizumab have shown reduced response to oral vaccines but not injectable ones. ${ }^{42}$ Interestingly, mTOR inhibitors have been shown to enhance immune response to certain vaccines. ${ }^{82}$

\section{Conclusions}

Biologic and targeted immunomodulators are associated with increased risk of particular bacterial, fungal, and viral infections based on their impact on the immune system. In order to minimize the potential infection risk, screening, immunization, monitoring, and prophylactic protocols should be implemented. Limited information exists on the risk of infections associated with the recently developed biologic agents including CD19, CD22; CD30; CD38; CD319; CD40; CCR4-targeted agents; second and third generation anti-CD20 monoclonal antibodies, second and third generations of BCR-ABL tyrosine kinase inhibitors; and their impact on patient response to immunization. Consequently, consensus guidelines do not make comprehensive recommendations regarding these agents. Further clinical research will guide us regarding the necessary safety measures to minimize the infection risk of these agents.

\section{Disclosure}

The authors report no conflicts of interest in this work.

\section{References}

1. Morrow TH, Felcone LH. Defining the difference: what makes biologics unique. Biotechnol Healthc. 2004;1(4):24-29.

2. Ferguson FM, Gray NS. Kinase inhibitors: the road ahead. Nat Rev Drug Discov. 2018;17(5):353-377. doi:10.1038/nrd.2018.21

3. Bresnihan B, Cunnane G. Infection complications associated with the use of biologic immunomodulators. Rheum Dis Clin North Am. 2003;29(1):185-202. doi:10.1016/S0889-857X(02)00101-1

4. Meroni PL, Zavaglia D, Girmenia C. Vaccinations in adults with rheumatoid arthritis in an era of new disease-modifying anti-rheumatic drugs. Clin Exp Rheumatol. 2018;36(2):317-328.

5. Henrickson SE, Ruffner MA, Kwan M. Unintended immunological consequences of biologic therapy. Curr Allergy Asthma Rep. 2016;16 (6):46. doi:10.1007/s11882-016-0624-7

6. Kaplan B, Bonagura VR. Secondary hypogammaglobulinemia: an increasingly recognized complication of treatment with immunomodulators and after solid organ transplantation. Immunol Allergy Clin North Am. 2019;39(1):31-47. doi:10.1016/j.iac.2018.08.005

7. Eisenberg R. Immune Compromise Associated with Biologics. Stiehm's Immune Deficiencies Academic Press; 2014:889-906.

8. Winthrop KL, Mariette X, Silva JT, et al. ESCMID Study Group for Infections in Compromised Hosts (ESGICH) Consensus Document on the safety of targeted and biological therapies: an infection diseases perspective (Soluble immune effector molecules [II]: agents targeting interleukins, immunoglobulins and complement factors). Clin Microbiol Infect. 2018;24:S21-S40. doi:10.1016/j.cmi.2018.02.002

9. Reinwald M, Silva JT, Mueller NJ, et al. ESCMID Study Group for Infections in Compromised Hosts (ESGICH) Consensus Document on the safety of targeted and biological therapies: an infection diseases perspective (Intracellular signaling pathways: tyrosine kinase and mTOR inhibitors). Clin Microbiol Infect. 2018;24:S53-70. doi:10.1016/j.cmi.2018.02.009 
10. Mikulska M, Lanini S, Gudiol C, et al. ESCMID Study Group for Infections in Compromised Hosts (ESGICH) Consensus Document on the safety of targeted and biological therapies: an infection diseases perspective (Agents targeting lymphoid cells surface antigens [I]: CD19, CD20 and CD52). Clin Microbiol Infect. 2018;24:S71-S82.

11. Redelman-Sidi G, Michielin O, Cervera C, et al. ESCMID study group for infections in compromised hosts (ESGICH) consensus document on the safety of targeted and biological therapies: an infection diseases perspective (Immune checkpoint inhibitors, cell adhesion inhibitors, sphingosine-1-phosphate receptor modulators and proteasome inhibitors). Clin Microbiol Infect. 2018;24:S95S107. doi:10.1016/j.cmi.2018.01.030

12. Drgona L, Gudiol C, Lanini S, et al. ESCMID Study Group for Infections in Compromised Hosts (ESGICH) Consensus Document on the safety of targeted and biological therapies: an infection diseases perspective (Agents targeting lymphoid or myeloid cells surface antigens [II]: CD22, CD30, CD33, CD38, CD40, SLAMF-7 and CCR4). Clin Microbiol Infect. 2018;24:S83-S94. doi:10.1016/ j.cmi.2018.03.022

13. Baddley JW, Cantini F, Goletti D, et al. ESCMID Study Group for Infections in Compromised Hosts (ESGICH) Consensus Document on the safety of targeted and biological therapies: an infectious diseases perspective (Soluble immune effector molecules [I]: antitumor necrosis factor- $\alpha$ agents). Clin Microbiol Infect. 2018;24: S10-S20. doi:10.1016/j.cmi.2017.12.025

14. Baden LR, Swaminathan S, Angarone M, et al. Prevention and treatment of cancer-related infections, Version 2.2016, NCCN Clinical Practice Guidelines in Oncology. J Natl Compr Canc Netw. 2016;14(7):882-913. doi:10.6004/jncen.2016.0093

15. Kotton CN, Kumar D, Caliendo AM, et al. The third international consensus guidelines on the management of cytomegalovirus in solid-organ transplantation. Transplantation. 2018;102(6):900931. doi:10.1097/TP.0000000000002191

16. Rubin LG, Levin MJ, Ljungman P, et al. 2013 IDSA clinical practice guideline for vaccination of the immunocompromised host. Clin Infect Dis. 2013;58(3):e44-e100.

17. Martin SI, Fishman JA, AST Infection Diseases Community of Practice. Pneumocystis pneumonia in solid organ transplantation. Am J Transplant. 2013;13(s4):272-279. doi:10.1111/ajt.2013.13.issue-s4

18. Van Assen S, Elkayam O, Agmon-Levin N, et al. Vaccination in adult patients with auto-immune inflammatory rheumatic diseases: a systematic literature review for the European League Against Rheumatism evidence-based recommendations for vaccination in adult patients with auto-immune inflammatory rheumatic diseases. Autoimmun Rev. 2011;10(6):341-352. doi:10.1016/j. autrev.2010.12.003

19. Salinas GF, De Rycke L, Barendregt B, et al. Anti-TNF treatment blocks the induction of T cell-dependent humoral responses. Ann Rheum Dis. 2013;72(6):1037-1043. doi:10.1136/annrheumdis2011-201270

20. Farraye FA, Melmed GY, Lichtenstein GR, et al. ACG clinical guideline: preventive care in inflammatory bowel disease. $\mathrm{Am} \mathrm{J}$ Gastroenterol. 2017;112(2):241. doi:10.1038/ajg.2016.537

21. Singh JA, Saag KG, Bridges SL, et al. 2015 American College of Rheumatology guideline for the treatment of rheumatoid arthritis. Arthritis Rheumatol. 2016;68(1):1-26. doi:10.1002/art.39480

22. Wijetilleka S, Jayne DR, Mukhtyar C, et al. Recommendations for the management of secondary hypogammaglobulinaemia due to B cell targeted immunomodulators in autoimmune rheumatic diseases. Rheumatology. 2018;58(5):889-896. doi:10.1093/rheumatology/key394

23. Mikulska M, Cesaro S, de Lavallade $\mathrm{H}$, et al. Vaccination of patients with haematological malignancies who did not have transplantations: guidelines from the 2017 European Conference on Infections in Leukaemia (ECIL 7). Lancet Infect Dis. 2019;19(6). doi:10.1016/S1473-3099(18)30601-7
24. Harpaz R, Ortega-Sanchez IR, Seward JF. Prevention of herpes zoster: recommendations of the Advisory Committee on Immunization Practices (ACIP). MMWR Recomm Rep. 2008;57(5):1-30.

25. Kroger AT, Duchin J, Vázquez M. General best practice guidelines for immunization. best practices guidance of the advisory committee on immunization practices (ACIP). Available from: https:// www.cdc.gov/vaccines/hcp/acip-recs/general-recs/index.html. Accessed January 29, 2020.

26. Maertens J, Cesaro S, Maschmeyer G, et al. ECIL guidelines for preventing Pneumocystis jirovecii pneumonia in patients with haematological malignancies and stem cell transplant recipients. $J$ Antimicrob Chemother. 2016;71(9):2397-2404. doi:10.1093/jac/ dkw157

27. Reddy KR, Beavers KL, Hammond SP, et al. American Gastroenterological Association Institute guideline on the prevention and treatment of hepatitis B virus reactivation during immunosuppressive drug therapy. Gastroenterology. 2015;148(1):215219. doi:10.1053/j.gastro.2014.10.039

28. Rieger CT, Liss B, Mellinghoff S, et al. Anti-infective vaccination strategies in patients with hematologic malignancies or solid tumors. Guideline of the Infectious Diseases Working Party (AGIHO) of the German Society for Hematology and Medical Oncology (DGHO). Ann Oncol. 2018;29(6):13541365. doi:10.1093/annonc/mdy117

29. Subramanian AK, Theodoropoulos NM. Mycobacterium tuberculosis infections in solid organ transplantation: Guidelines from the infectious diseases community of practice of the American Society of Transplantation . Clin Transplant. 2019 Sep;33(9):e13513. doi:10.1111/ctr.13513

30. Loomba R, Liang TJ. Hepatitis B reactivation associated with immune suppressive and biological modifier therapies: current concepts, management strategies, and future directions. Gastroenterology. 2017;152 (6):1297-1309. doi:10.1053/j.gastro.2017.02.009

31. Ciardi MR, Iannetta M, Zingaropoli MA, et al. Reactivation of hepatitis B virus with immune-escape mutations after ocrelizumab treatment for multiple sclerosis. Open Forum Infect Dis. 2018;6(1): ofy 356.

32. Li HR, Huang JJ, Guo HQ, et al. Comparison of entecavir and lamivudine in preventing hepatitis B reactivation in lymphoma patients during chemotherapy. J Viral Hepat. 2011;18(12):877883. doi:10.1111/j.1365-2893.2010.01386.x

33. Picardi M, Della Pepa R, Giordano C, et al. Tenofovir vs lamivudine for the prevention of hepatitis $\mathrm{B}$ virus reactivation in advanced-stage DLBCL. Blood. 2019;133(5):498. doi:10.1182/ blood-2018-10-878892

34. Chen YM, Huang WN, Wu YD, et al. Reactivation of hepatitis B virus infection in patients with rheumatoid arthritis receiving tofacitinib: a real-world study. Ann Rheum Dis. 2018;77(5):780-782. doi:10.1136/annrheumdis-2017-211322

35. Göksu SS, Bilal Ş, Coşkun HŞ. Hepatitis B reactivation related to everolimus. World J Hepatol. 2013;5(1):43. doi:10.4254/wjh.v5.i1.43

36. Mizuno S, Yamagishi Y, Ebinuma H, et al. Progressive liver failure induced by everolimus for renal cell carcinoma in a 58-year-old male hepatitis B virus carrier. Clin J Gastroenterol. 2013;6(2):188192. doi:10.1007/s12328-013-0371-4

37. Swan CD, Reid AB. Three cases of presumed pneumocystis pneumonia in patients receiving bortezomib therapy for multiple myeloma. IDCases. 2014;1(3):32-35. doi:10.1016/j.idcr.2014.04.002

38. Wondergem MJ, Grünberg K, Wittgen BP, et al. Interstitial pneumonitis caused by Pneumocystis jirovecii pneumonia (PCP) during bortezomib treatment. Histopathology. 2009;54(5):631-633. doi:10.1111/ j.1365-2559.2009.03263.x

39. Tabanor JA, Lakshminarayanan S. Do patients on biologic drugs for rheumatic disease need PCP prophylaxis? Cleve Clin J Med. 2019;86(7):449-453. doi:10.3949/ccjm.86a.18084 
40. Mori S, Yoshitama T, Hidaka T, et al. Comparative risk of hospitalized infection between biological agents in rheumatoid arthritis patients: a multicenter retrospective cohort study in Japan. PLoS One. 2017;12(6):e0179179. doi:10.1371/journal.pone.0179179

41. Lee R, Nayernama A, Jones SC, et al. Ibrutinib-associated Pneumocystis jirovecii pneumonia. Am J Hematol. 2017;92(11): E646-E648. doi:10.1002/ajh.24890

42. Noreña I, Fernández-Ruiz M, Aguado JM. Viral infections in the biologic therapy era. Expert. Rev Anti Infect Ther. 2018;16 (10):781-791. doi:10.1080/14787210.2018.1521270

43. Carson KR, Focosi D, Major EO, et al. Monoclonal antibody-associated progressive multifocal leucoencephalopathy in patients treated with rituximab, natalizumab, and efalizumab: a Review from the Research on Adverse Drug Events and Reports (RADAR) Project. Lancet Oncol. 2009;10(8):816-824. doi:10.1016/S1470-2045(09) 70161-5

44. Blankenbach K, Schwab N, Hofner B, et al. Natalizumab-associated progressive multifocal leukoencephalopathy in Germany. Neurology. 2019;92(19):e2232-e2233. doi:10.1212/WNL.0000000000007451

45. Siegler JE, Galetta S. Editors' note: progressive multifocal leukoencephalopathy after fingolimod treatment. Neurology. 2019;92 (3):150. doi:10.1212/WNL.0000000000006772

46. Lalive PH, Roth S, Du Pasquier R. Reader response: progressive multifocal leukoencephalopathy after fingolimod treatment. Neurology. 2019;92(3):151. doi:10.1212/WNL.0000000000006773

47. Bigaut K, De Seze J, Collongues N. Ocrelizumab for the treatment of multiple sclerosis. Expert Rev Neurother. 2019;19(2):97-108. doi:10.1080/14737175.2019.1561284

48. Williamson EM, Berger JR. Diagnosis and treatment of progressive multifocal leukoencephalopathy associated with multiple sclerosis therapies. Neurotherapeutics. 2017;14(4):961-973. doi:10.1007/ s13311-017-0570-7

49. Ai JW, Zhang S, Ruan QL, et al. The risk of tuberculosis in patients with rheumatoid arthritis treated with tumor necrosis factor- $\alpha$ antagonist: a meta analysis of both randomized controlled trials and registry/cohort studies. J Rheumatol. 2015;42(12):2229-2237. doi:10.3899/jrheum.150057

50. Bongartz T, Sutton AJ, Sweeting MJ, et al. Anti-TNF antibody therapy in rheumatoid arthritis and the risk of serious infections and malignancies: systematic review and meta-analysis of rare harmful effects in randomized controlled trials. JAMA. 2006;295 (19):2275-2285. doi:10.1001/jama.295.19.2275

51. Souto A, Maneiro JR, Salgado E, et al. Risk of tuberculosis in patients with chronic immune-mediated inflammatory diseases treated with biologics and tofacitinib: a systematic review and metaanalysis of randomized controlled trials and long-term extension studies. Rheumatology. 2014;53(10):1872-1885. doi:10.1093/rheumatology/keu172

52. Brassard P, Kezouh A, Suissa S. Antirheumatic drugs and the risk of tuberculosis. Clin Infect Dis. 2006;43(6):717-722.

53. Lussana F, Cattaneo M, Rambaldi A, et al. Ruxolitinib-associated infections: a systematic review and meta-analysis. Am J Hematol. 2018;93(3):339-347. doi:10.1002/ajh.24976

54. Cantini F, Nannini C, Niccoli L, et al. Risk of tuberculosis reactivation in patients with rheumatoid arthritis, ankylosing spondylitis, and psoriatic arthritis receiving non-anti-TNF-targeted biologics. Mediators Inflamm. 2017;2017:8909834. doi:10.1155/2017/8909834

55. Helfrich M, Ison MG. Opportunistic infections complicating solid organ transplantation with alemtuzumab induction. Transpl Infect Dis. 2015;17(5):627-636. doi:10.1111/tid.2015.17.issue-5

56. Au WY, Leung AY, Eric WC, et al. High incidence of tuberculosis after alemtuzumab treatment in Hong Kong Chinese patients. Leuk Res. 2008;32(4):547-551. doi:10.1016/j.leukres.2007.06.010
57. Jeon SY, Yhim HY, Lee NR, et al. Everolimus-induced activation of latent Mycobacterium tuberculosis infection in a patient with metastatic renal cell carcinoma. Korean J Intern Med. 2017;32 (2):365-368. doi:10.3904/kjim.2015.121

58. Coriat R, Mir O, Ropert S, et al. Reactivation of tuberculosis during temsirolimus therapy. Invest New Drugs. 2011;29(6):1494-1496. doi:10.1007/s10637-010-9487-2

59. Guirao-Arrabal E, Santos F, Redel-Montero J, et al. Risk of tuberculosis after lung transplantation: the value of pretransplant chest computed tomography and the impact of $\mathrm{m}$ TOR inhibitors and azathioprine use. Transpl Infect Dis. 2016;18(4):512-519. doi:10.1111/tid.12555

60. Nucci M, Anaissie E. Infections in patients with multiple myeloma in the era of high-dose therapy and novel agents. Clin Infect Dis. 2009;49(8):1211-1225. doi:10.1086/599191

61. Winthrop KL, Yamanaka H, Valdez H, et al. Herpes zoster and tofacitinib therapy in patients with rheumatoid arthritis. Arthritis Rheumatol. 2014;66(10):2675-2684. doi:10.1002/art.v66.10

62. Yun H, Xie F, Delzell E, et al. Risks of herpes zoster in patients with rheumatoid arthritis according to biologic disease-modifying therapy. Arthritis Care Res (Hoboken). 2015;67(5):731-736. doi:10.1002/acr.22470

63. Arvin AM, Wolinsky JS, Kappos L, et al. Varicella-zoster virus infections in patients treated with fingolimod: risk assessment and consensus recommendations for management. JAMA Neurol. 2015;72(1):31-39. doi:10.1001/jamaneurol.2014.3065

64. Buonomo AR, Zappulo E, Viceconte G, et al. Risk of opportunistic infections in patients treated with alemtuzumab for multiple sclerosis. Expert Opin Drug Saf. 2018;17(7):709-717. doi:10.1080/ 14740338.2018.1483330

65. Prestes DP, Arbona E, Nevett-Fernandez A, et al. Dasatinib use and risk of cytomegalovirus reactivation after allogeneic hematopoieticcell transplantation. Clin Infect Dis. 2017;65(3):510-513. doi:10.1093/cid/cix325

66. Committee for Medicinal Products for Human Use (CHMP). International non- proprietary name: remicade. European Medicines Agency $E M A / C H M P / 47828 / 2019$. Available from: https://www.ema. europa.eu/en/documents/product-information/remicade-epar-productinformation en.pdf. Accessed January 29, 2020.

67. Committee for Medicinal Products for Human Use (CHMP). International non- proprietary name: kineret. Available from: https://www.ema.europa.eu/en/documents/product-information/ kineret-epar-product-information_en.pdf. Accessed January 29, 2020.

68. Committee for Medicinal Products for Human Use (CHMP). International non- proprietary name: ilaris EMEA/H/C/001109. Available from: https://www.ema.europa.eu/en/documents/productinformation/ilaris-epar-product-information_en.pdf. Accessed January 29, 2020.

69. Alten R, Bingham CO, Cohen SB, et al. Antibody response to pneumococcal and influenza vaccination in patients with rheumatoid arthritis receiving abatacept. BMC Musculoskelet Disord. 2016;17(1):231. doi:10.1186/s12891-016-1082-z

70. Chatham W, Chadha A, Fettiplace J, et al. A randomized, openlabel study to investigate the effect of belimumab on pneumococcal vaccination in patients with active, autoantibody-positive systemic lupus erythematosus. Lupus. 2017;26(14):1483-1490. doi:10.1177/ 0961203317703495

71. Kaufman M, Pardo G, Rossman H, Sweetser MT, Forrestal F, Duda P. Natalizumab treatment shows no clinically meaningful effects on immunization responses in patients with relapsing-remitting multiple sclerosis. J Neurol Sci. 2014;341(1-2):22-27. doi:10.1016/j. jns.2014.03.035 
72. Brodmerkel C, Wadman E, Langley RG, et al. Immune response to pneumococcus and tetanus toxoid in patients with moderate-tosevere psoriasis following long-term ustekinumab use. J Drugs Dermatol. 2013;12(10):1122-1129.

73. Chioato A, Noseda E, Stevens M, et al. Treatment with the interleukin-17A-blocking antibody secukinumab does not interfere with the efficacy of influenza and meningococcal vaccinations in healthy subjects: results of an open-label, parallel-group, randomized single-center study. Clin Vaccine Immunol. 2012;19(10):1597-1602. doi:10.1128/CVI.00386-12

74. Mori S, Ueki Y, Hirakata N, et al. Impact of tocilizumab therapy on antibody response to influenza vaccine in patients with rheumatoid arthritis. Ann Rheum Dis. 2012;71(12):2006-2010. doi:10.1136/ annrheumdis-2012-201950

75. Celotto K, Nair J, Lee K. The effect of bortezomib treatment on antibody titers against common viral and vaccine antigens. Clin Lymph Myelom Leuk. 2015;15:e179. doi:10.1016/j. clm1.2015.07.402

76. Berger T, Elovaara I, Fredrikson S, et al. Alemtuzumab use in clinical practice: recommendations from European multiple sclerosis experts. CNS Drugs. 2017;31(1):33-50. doi:10.1007/s40263016-0394-8

77. Issa NC, Baden LR. Current issues in vaccines for adult patients with hematologic malignancies. J Natl Compr Canc Netw. 2012;10 (11):1447-1454. doi:10.6004/jnccn.2012.0147

78. Committee for Medicinal Products for Human Use (CHMP). International non- proprietary name: raptiva EMEA/H/C/000542. Available from: https://www.ema.europa.eu/en/documents/productinformation/raptiva-epar-product-information_en.pdf. Accessed January 29, 2020.

79. De Lavallade H, Khoder A, Hart M, et al. Tyrosine kinase inhibitors impair B-cell immune responses in CML through off-target inhibition of kinases important for cell signaling. Blood. 2013;122 (2):227-238. doi:10.1182/blood-2012-11-465039

80. Winthrop KL, Silverfield J, Racewicz A, et al. The effect of tofacitinib on pneumococcal and influenza vaccine responses in rheumatoid arthritis. Ann Rheum Dis. 2016;75(4):687-695. doi:10.1136/annrheumdis-2014-207191

81. Douglas AP, Trubiano JA, Barr I, Leung V, Slavin MA, Tam CS. Ibrutinib may impair serological responses to influenza vaccination. Haematologica. 2017;102(10):e397. doi:10.3324/haematol.2017. 164285

82. Struijk GH, Minnee RC, Koch SD, et al. Maintenance immunosuppressive therapy with everolimus preserves humoral immune responses. Kidney Int. 2010;78(9):934-940. doi:10.1038/ki.2010.269

83. Barmettler S, Ong MS, Farmer JR, et al. Association of immunoglobulin levels, infection risk, and mortality with rituximab and hypogammaglobulinemia. JAMA Netw Open. 2018;1(7):e184169. doi:10.1001/jamanetworkopen.2018.4169

84. Danovitch GM, editor. Handbook of Kidney Transplantation. Lippincott Williams \& Wilkins; 2017 June, 13.

85. Terrault NA, Lok AS, McMahon BJ, et al. Update on prevention, diagnosis, and treatment of chronic hepatitis B: AASLD 2018 hepatitis B guidance. Hepatology. 2018;67(4):1560-1599. doi:10.1002/hep. 29800

86. Winthrop KL. Tumor necrosis factor-alpha inhibitors: bacterial, viral, and fungal infections. Bow Blumberg EA, Bond Sh, editors. UpToDate Inc.2019. Available from: https://www.uptodate.com/ contents/tumor-necrosis-factor-alpha-inhibitors-bacterial-viral-andfungal-infections. Accessed January 29, 2020.

87. Morrison VA. Prevention of infections in patients with chronic lymphocytic leukemia. Bow E, Throner AR, editors. UpToDate Inc. 2019. Available from: https://www.uptodate.com/contents/pre vention-of-infections-in-patients-with-chronic-lymphocytic-leuke mia. Accessed January 29, 2020.
88. Puzanov I, Diab A, Abdallah K, et al. Managing toxicities associated with immune checkpoint inhibitors: consensus recommendations from the Society for Immunotherapy of Cancer (SITC) Toxicity Management Working Group. J Immunother Cancer. 2017;5(1):95. doi:10.1186/s40425-017-0300-z

89. Fishman JA, Gans H; AST Infectious Diseases Community of Practice. Pneumocystis jiroveci in solid organ transplantation: guidelines from the american society of transplantation infectious diseases community of practice. Clin Transplant. 2019;33:e13587.

90. Casulo C, Maragulia J, Zelenetz AD. Incidence of hypogammaglobulinemia in patients receiving rituximab and the use of intravenous immunoglobulin for recurrent infections. Clin Lymph Myelom Leuk. 2013;13(2):106-111. doi:10.1016/j.clml.2012.11.011

91. Yilmaz E, Mahani MG, Bilen MA, et al. Clinical characteristics of rituximab-induced late onset neutropenia. Am J Hematol. 2010;85 (10):810-812. doi:10.1002/ajh.21818

92. Salmon JH, Cacoub P, Combe B, et al. Late-onset neutropenia after treatment with rituximab for rheumatoid arthritis and other autoimmune diseases: data from the autoimmunity and rituximab registry. RMD Open. 2015;1(1):e000034. doi:10.1136/rmdopen-2014000034

93. Cohen BA. Late-onset neutropenia following ocrelizumab therapy for multiple sclerosis. Neurology. 2019;92(9):435-436. doi:10.1212/ WNL.0000000000006924

94. Committee for Medicinal Products for Human Use (CHMP) International non- proprietary name: xeljanz EMEA $/ \mathrm{H} / \mathrm{C} /$ 004214. Available from: https://www.ema.europa.eu/en/docu ments/product-information/xeljanz-epar-product-information_en. pdf. Accessed January 29, 2020.

95. Committee for Medicinal Products for Human Use (CHMP) International non- proprietary name: Jakavi - EMEA/H/C/002464. Available from: https://www.ema.europa.eu/en/documents/productinformation/jakavi-epar-product-information_en.pdf. Accessed February 10, 2020.

96. Click B, Regueiro M. Managing Risks with Biologics. Curr Gastroenterol Rep. 2019;21(1):1. doi:10.1007/s11894-019-0669-6

97. Committee for Medicinal Products for Human Use (CHMP). International non- proprietary name: gilenya $\mathrm{EMEA} / \mathrm{H} / \mathrm{C} /$ 002202. Available from: https://www.ema.europa.eu/en/docu ments/product-information/gilenya-epar-product-information_en. pdf. Accessed January 29, 2020.

98. Furer V, Rondaan C, Heijstek MW, et al. 2019 update of EULAR recommendations for vaccination in adult patients with autoimmune inflammatory rheumatic diseases. Ann Rheum Dis. 2020;79 (1):39-52. doi:10.1136/annrheumdis-2019-215882

99. Committee for Medicinal Products for Human Use (CHMP) International non- proprietary name: humira EMEA/H/C/000481. Available from: https://www.ema.europa.eu/en/documents/productinformation/humira-epar-product-information_en.pdf. Accessed January 29, 2020.

100. Committee for Medicinal Products for Human Use (CHMP). International non- proprietary name: enbrel. EMEA/H/C/0002621. Available from: https://www.ema.europa.eu/en/documents/productinformation/enbrel-epar-product-information_en.pdf. Accessed January 29, 2020.

101. Committee for Medicinal Products for Human Use (CHMP). International non- proprietary name: Simponi. European Medicines Agency. EMEA/H/C/000992. Available from: https://www.ema. europa.eu/en/documents/product-information/simponi-epar-productinformation_en.pdf. Accessed January 29, 2020.

102. Committee for Medicinal Products for Human Use (CHMP). International non- proprietary name: cimzia. EMEA/H/C/001037. Available from: https://www.ema.europa.eu/en/documents/productinformation/cimzia-epar-product-information_en.pdf. Accessed January 29, 2020. 
103. Papp KA, Haraoui B, Kumar D, et al. Vaccination guidelines for patients with immune-mediated disorders on immunosuppressive therapies. J Cutan Med Surg. 2019;23(1):50-74. doi:10.1177/ 1203475418811335

104. Committee for Medicinal Products for Human Use (CHMP). International non- proprietary name: regeneron EMEA/H/C/ 001047. Available from: https://www.ema.europa.eu/en/docu ments/product-information/rilonacept-regeneron-epar-product-infor mation_en.pdf. Accessed January 29, 2020.

105. Committee for Medicinal Products for Human Use (CHMP) International non- proprietary name: blincyto EMEA/H/C/003731 https://www.ema.europa.eu/en/documents/product-information/blin cyto-epar-product-information_en.pdf. Accessed January 29, 2020.

106. Committee for Medicinal Products for Human Use (CHMP). International non- proprietary name: ocrevus EMA/790835/2017. Available from: https://www.ema.europa.eu/en/documents/productinformation/ocrevus-epar-product-information_en.pdf. Accessed January 29, 2020.

107. Stokmaier D, Winthrop K, Chognot C, et al. Effect of ocrelizumab on vaccine responses in patients with multiple sclerosis (S36. 002).

108. Beaulieu DB, Ananthakrishnan AN, Martin C, et al. Use of biologic therapy by pregnant women with inflammatory bowel disease does not affect infant response to vaccines. Clin Gastroenterol Hepatol. 2018;16(1):99-105. doi:10.1016/j.cgh.2017.08.041

109. Committee for Medicinal Products for Human Use (CHMP). International non- proprietary name: arzerra EMEA/H/C/ 001131. Available from: https://www.ema.europa.eu/en/docu ments/product-information/arzerra-epar-product-information_en. pdf. Accessed January 29, 2020.
110. Committee for Medicinal Products for Human Use (CHMP). International non- proprietary name: Gazyvaro - EMEA/H/C/ 002799. Available from:https:/www.ema.europa.eu/en/documents/ product-information/gazyvaro-epar-product-information_en.pdf. Accessed February 5, 2020.

111. Committee for Medicinal Products for Human Use (CHMP). International non- proprietary name: mabcampath $\mathrm{EMEA} / \mathrm{H} / \mathrm{C} /$ 000353. Available from: https://www.ema.europa.eu/en/docu ments/product-information/mabcampath-epar-product-information_ en.pdf. Accessed January 29, 2020.

112. Committee for Medicinal Products for Human Use (CHMP). International non- proprietary name: orenica $\mathrm{EMEA} / \mathrm{H} / \mathrm{C} /$ 000701. Available from: https://www.ema.europa.eu/en/docu ments/product-information/orencia-epar-product-information_en. pdf. Accessed January 29, 2020.

113. Committee for Medicinal Products for Human Use (CHMP). International non- proprietary name: stelara EMEA/H/C/000958. Available from: https://www.ema.europa.eu/en/documents/productinformation/stelara-epar-product-information_en.pdf. Accessed January 29, 2020.

114. Danziger Isakov L, Kumar D; AST ID Community of Practice. Vaccination of solid organ transplant candidates and recipients: guidelines from the American society of transplantation infectious diseases community of practice. Clin Transplant. 2019;33:e13563.
Infection and Drug Resistance

\section{Publish your work in this journal}

Infection and Drug Resistance is an international, peer-reviewed openaccess journal that focuses on the optimal treatment of infection (bacterial, fungal and viral) and the development and institution of preventive strategies to minimize the development and spread of resistance. The journal is specifically concerned with the epidemiology of

\section{Dovepress}

antibiotic resistance and the mechanisms of resistance development and diffusion in both hospitals and the community. The manuscript management system is completely online and includes a very quick and fair peerreview system, which is all easy to use. Visit http://www.dovepress.com/ testimonials.php to read real quotes from published authors. 